\title{
Effect of Anisotropy and Destructuration on Behavior of Haarajoki Test Embankment
}

\author{
Abdulazim Yildiz'; Minna Karstunen²; and Harald Krenn ${ }^{3}$
}

\begin{abstract}
This paper investigates the influence of anisotropy and destructuration on the behavior of Haarajoki test embankment, which was built by the Finnish National Road Administration as a noise barrier in 1997 on a soft clay deposit. Half of the embankment is constructed on an area improved with prefabricated vertical drains, while the other half is constructed on the natural deposit without any ground improvement. The construction and consolidation of the embankment is analyzed with the finite-element method using three different constitutive models to represent the soft clay. Two recently proposed constitutive models, namely S-CLAY1 which accounts for initial and plastic strain induced anisotropy, and its extension, called S-CLAY1S which accounts, additionally, for interparticle bonding and degradation of bonds, were used in the analysis. For comparison, the problem is also analyzed with the isotropic modified cam clay model. The results of the numerical analyses are compared with the field measurements. The simulations reveal the influence that anisotropy and destructuration have on the behavior of an embankment on soft clay.
\end{abstract}

DOI: 10.1061/(ASCE)1532-3641(2009)9:4(153)

CE Database subject headings: Embankments; Anisotropy; Destruction; Finite element method; Drainage.

\section{Introduction}

In many regions of the world, population growth, economic needs, and environmental constraints necessitate construction of structures on soft clay deposits, which were considered unsuitable for construction just a couple of decades ago. Modeling of soft clays has always been one of the main focuses in geotechnical engineering. The stress-strain behavior of natural soft soils is highly nonlinear and very complex, as different fundamental features of soil, such as anisotropy, creep, and destructuration, influence its response to foundation loading. Current geotechnical design practice routinely relies on simplified theories, and the methods used are at best very crude and conservative (and hence uneconomical), or at worst unsafe.

Advanced geotechnical design on soft clays has often been based on finite-element analyses using isotropic elasto-plastic soil models, such as modified cam clay (Roscoe and Burland 1968) and its isotropic extensions. Natural clays, however, are highly anisotropic because of the mode of their sedimentation, the preferred orientation of plate-shaped clay particles during deposition, and the subsequent consolidation under self-weight loading (Tavenas and Leroueil 1977; Ladd et al. 1977; Diaz-Rodriguez et al. 1992). Anisotropy can influence both elastic and plastic behavior. For normally consolidated or lightly overconsolidated soft clays, plastic deformations are likely to dominate for many problems, such as the embankment loading considered in this paper. Most natural clays are structured (Leroueil and Vaughan 1990; Burland 1990), which reflects the soil composition, history, present state, and environment. The structure is composed of fabric (the geometrical arrangement of soil particles and particle contacts), which is often anisotropic, and some form of apparent interparticle bonding. Interparticle bonding results from the mineralogy and pore-water composition combined with complex geochemical processes, and it gives the soil additional resistance to yielding. Plastic straining modifies the anisotropy, and gradually breaks the apparent bonding, due to slippage at interparticle contacts and subsequent rearrangement and realignment of particles. The degradation of bonding due to plastic strains is referred to as destructuration, and it significantly affects the mechanical behavior of soft clays (Rouainia and Muir Wood 2000; Leroueil and Vaughan 1990). Indeed, the mechanical behavior of natural soils is controlled by the bond degradation and the intrinsic properties of the soils (Burland 1990).

When constructing embankments on soft compressible soils with low bearing capacity and low hydraulic conductivity, the stability and time required for consolidation are the two major considerations in the design ( $\mathrm{Li}$ and Rowe 2002). Prefabricated vertical drains (PVDs) are commonly used to shorten the consolidation times on thick soft deposits by providing short horizontal drainage paths (Jamiolkowski et al. 1983). The PVD is a slender, synthetic drainage element comprised of a drainage core wrapped in a geotextile filter. However, in recent years, the technique of reinforcing the embankment at the base using geosynthetic reinforcement to improve its short-term stability has become popular (Sharma and Bolton 2001; Varuso et al. 2005; Rowe and Li 2005; Sarsby 2007). The use of geosynthetic reinforcement in combination with prefabricated vertical drains also has the potential to allow the cost-effective construction of substantially higher embankments in considerably shorter time periods than conventional construction methods ( $\mathrm{Li}$ and Rowe 2001; Rowe and 
Taechakumthorn 2007). PVDs also work together with geosynthetic reinforcement to minimize the differential settlement and lateral deformation of the foundation and the combined use of the geosynthetic reinforcement and PVDs enhances embankment performance substantially more than the use of either method of soil improvement alone (Rowe and Taechakumthorn 2008).

The finite-element method (FEM) is often used for predicting the performance of embankments constructed on soft soils and extensive research has been carried out in this area for the past several years (Rowe and Soderman 1984; Schaefer and Duncan 1988; Hird and Kwok 1989; Sanchez and Sagaseta 1990; Chai and Bergado 1993; Bergado et al. 1995; Indraratna and Redana 1997, 2000; Borges et al. 2000; Neher et al. 2001; Bergado et al. 2002; Shen et al. 2005; Karstunen et al. 2005; Gnanendran et al. 2006). Isotropic elasto-plastic models (Roscoe and Schofield 1963; Roscoe and Burland 1968; Chen 1982) have been commonly used successfully to predict the behavior of embankment. However, it was concluded that even allowing for consolidation, these models was not adequate for accurately and simultaneously predicting multiple characteristics of the embankment behavior (e.g., vertical and horizontal deformations, pore pressure). Neglecting the effects of anisotropy and/or destructuration may lead to inaccurate predictions of soft clay response (Karstunen et al. 2005). Due to the viscous nature of some soft clayey foundations, the time dependency of stress-strain behavior of soft clays also has a significant influence on the behavior of embankments. For example, Rowe et al. (1996) showed that in order to accurately predict the responses of the Sackville test embankment on a rate sensitive soil, it was essential to consider the effect of soil viscosity. Rowe and Hinchberger (1998) proposed an elasto-viscoplastic constitutive model and demonstrated that the proposed model could adequately describe the behavior of the Sackville test embankment. Therefore, there is a need for a constitutive model that can adequately account for fundamental features of soil, such as anisotropy, destructuration, and creep in a relatively simple manner.

In recent years there have been considerable developments in understanding the behavior of soft clays and a number of elastoplastic constitutive models incorporating features such as anisotropy and/or destructuration have been published in the literature (Whittle and Kavvadas 1994; Kavvadas and Amorosi 2000; Rouainia and Muir Wood 2000; Liu and Carter 2002; Nova et al. 2003; Dafalias et al. 2006). Most of these models, however, do not take into account the combined effect of anisotropy and destructuration. Furthermore, the application of these models to practical geotechnical design is not common, because the determination of the model input parameters is often cumbersome, and it may even require nonstandard laboratory tests.

The S-CLAY1 model proposed by Wheeler et al. (2003) is an elasto-plastic model that attempts to provide a realistic representation of the influence of plastic anisotropy while still keeping the model relatively simple. The model parameters can be determined from the results of standard laboratory tests by using well-defined methodologies. Furthermore, the model has been successfully validated against experimental data on several natural and reconstituted clays (Koskinen et al. 2002a, b; Wheeler et al. 2003, Karstunen and Koskinen 2008). The extension of the model called S-CLAY1S (Karstunen et al. 2005) incorporates the combined effect of anisotropy, bonding, and destructuration. S-CLAY1S accounts for the additional strength given by the apparent bonds with a so-called intrinsic yield curve, a concept originally proposed by Gens and Nova (1993). In this study, the S-CLAY1 (Wheeler et al. 2003) and S-CLAY1S (Karstunen et al. 2005)

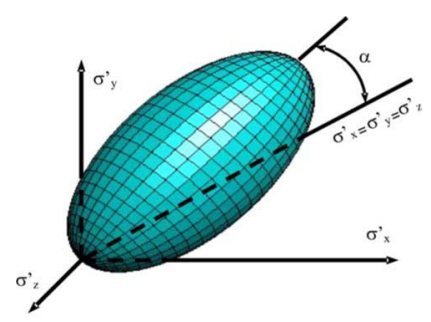

(a)

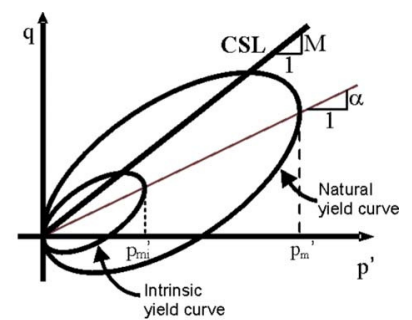

(b)
Fig. 1. S-CLAY1S yield surface in: (a) three-dimensional stress space; (b) triaxial stress space

models are applied to represent the soft clay under Haarajoki test embankment in Finland. The results of numerical studies are compared with field observations. For comparison, the problem is also analyzed with the isotropic modified cam clay model (Roscoe and Burland 1968).

The true modeling of an embankment with vertical drains requires three-dimensional (3D) analyses. Most analyses however have adopted plane strain conditions. The problem of water flow into a vertical drain under an infinitely wide fill is axisymmetric, and therefore the vertical drain system must be converted into an equivalent plane strain model for numerical simulations. Several authors (Hird et al. 1992, 1995; Chai et al. 1995, 2001; Indraratna and Redana 1997) have shown that vertical drains can be effectively modeled by using appropriate mapping methods to represent the typical arrangement of vertical drains in plane strain finite-element analyses. However, certain simplifying assumptions are made, as discussed later on. The two most useful mapping approaches from a computational point of view are those by Chai et al. (2001) and Hird et al. (1992), as accounting for the effects of the smear zones around the drains does not require separate discretization. In this paper the combined mapping purposed by Hird et al. (1992) is used in the analysis of the behavior of PVD improved subsoil in combination with complex elastoplastic models, namely MCC, S-CLAY1, and S-CLAY1S.

First, a brief description of constitutive models is given, followed by information about the embankment geometry, material parameters, and initial conditions, as necessary for the input of numerical analyses. Finally, the results of numerical analyses of Haarajoki embankment on soft clay deposit with and without PVD improvement are compared with the corresponding field observations.

\section{Constitutive Models}

The S-CLAY1S model is a critical state model with anisotropy of plastic behavior represented through an inclined yield surface and a hardening law to model the development or erasure of fabric anisotropy during plastic straining. Additionally, the model accounts for destructuration. In three-dimensional stress space the yield surface of the S-CLAY1S model is a sheared ellipsoid [Fig. 1(a)], given by

$$
\begin{aligned}
f & =\frac{3}{2}\left[\left\{\boldsymbol{\sigma}_{d}-p^{\prime} \boldsymbol{\alpha}_{d}\right\}^{T}\left\{\boldsymbol{\sigma}_{d}-p^{\prime} \boldsymbol{\alpha}_{d}\right\}\right]-\left[M^{2}-\frac{3}{2}\left\{\boldsymbol{\alpha}_{d}\right\}^{T}\left\{\boldsymbol{\alpha}_{d}\right\}\right]\left(p_{m}^{\prime}-p^{\prime}\right) p^{\prime} \\
& =0
\end{aligned}
$$

where $\boldsymbol{\sigma}_{d}=$ deviatoric deviatoric stress tensor; $p^{\prime}=$ mean effective stress; $\boldsymbol{\alpha}_{d}=$ deviatoric fabric tensor (a dimensionless second-order tensor that is defined analogously to the deviatoric stress tensor; 


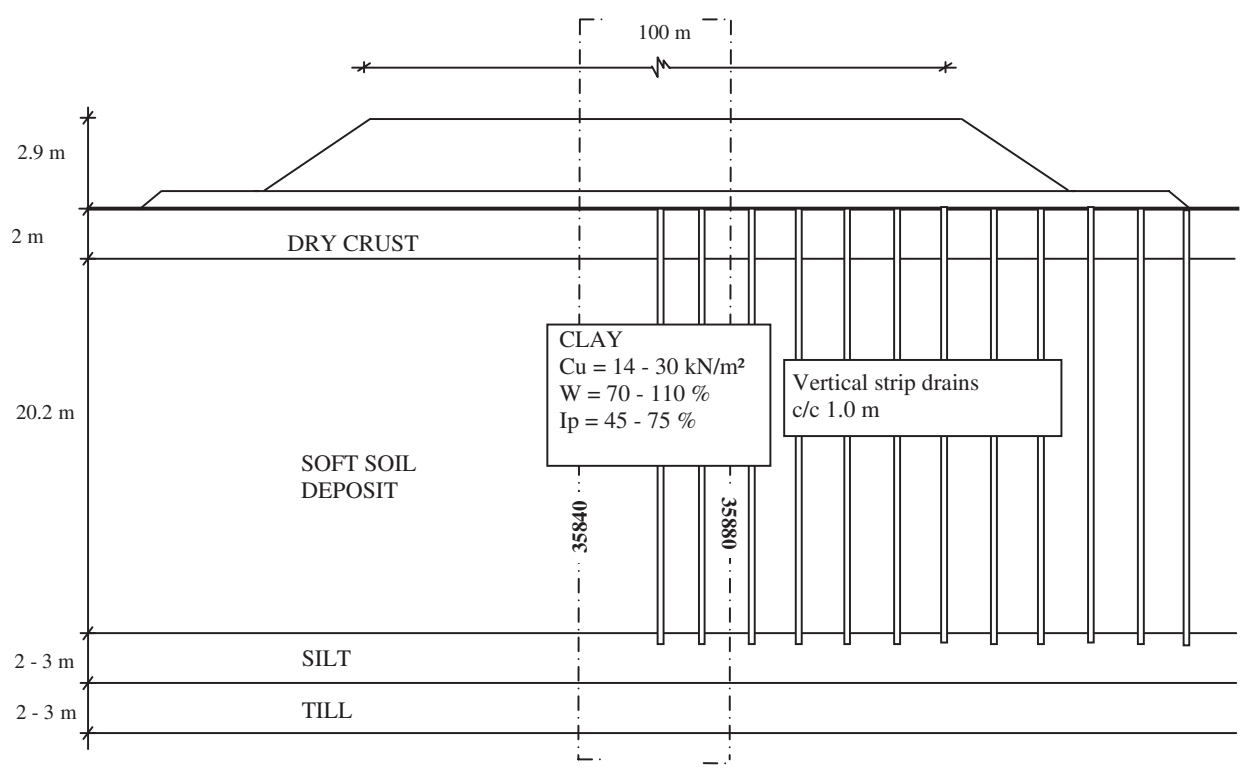

(a)

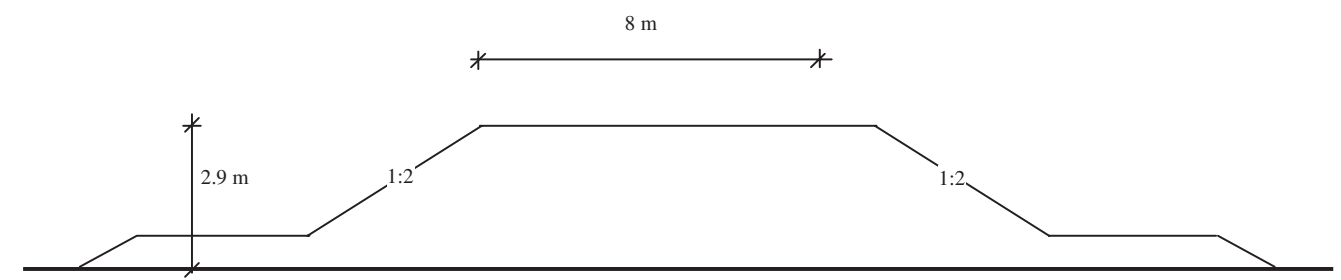

(b)

Fig. 2. Haarajoki test embankment: (a) longitudinal section; (b) cross section

see Wheeler et al. 2003 for details); $M=$ value of the stress ratio at critical state; and $p_{m}^{\prime}$ defines the size of the yield surface of the natural clay. Eq. (1) shows that the generalized version of the yield surface cannot be expressed solely in terms of stress invariants. Fig. 1(a) illustrates the shape of the S-CLAY1S yield surface in three-dimensional stress space, for the case where the principal axes of both the stress tensor and the fabric tensor coincide with the $x, y$, and $z$ directions.

Within the yield surface there is a notional "intrinsic yield surface" for the equivalent unbonded soil with the same fabric, which is assumed to be of the same shape and orientation as the real yield surface, but smaller in size. The size of the intrinsic yield surface is specified by a parameter $p_{m i}^{\prime}$, and this is related to the size $p_{m}^{\prime}$ of the yield surface for the natural soil by parameter $\chi$, defining the current degree of bonding

$$
p_{m}^{\prime}=(1+\chi) p_{m i}^{\prime}
$$

For the simplified conditions of a triaxial test on a previously one-dimensionally consolidated sample, it can be assumed that the horizontal plane in the triaxial sample coincides with the plane of isotropy of the sample. In this special case, the fabric tensor can be replaced by a scalar parameter $\alpha$, defined as

$$
\alpha^{2}=\frac{3}{2}\left\{\boldsymbol{\alpha}_{d}\right\}^{T}\left\{\boldsymbol{\alpha}_{d}\right\}
$$

which is a measure of the degree of plastic anisotropy of the soil. The yield curves of the S-CLAY1S model can then be visualized by Fig. 1(b). For the sake of simplicity, the S-CLAY1S model assumes isotropic elastic behavior, of the same form as in the modified cam clay model (Roscoe and Burland 1968), and an associated flow rule.

S-CLAY1S incorporates three hardening laws. The first of these relates the change in the size of the intrinsic yield surface to the plastic volumetric strain increment $d \varepsilon_{v}^{p}$

$$
d p_{m i}^{\prime}=\frac{v p_{m i}^{\prime}}{\lambda_{i}-\kappa} d \varepsilon_{v}^{p}
$$

where $\lambda_{i}=$ gradient of the intrinsic normal compression line (for a reconstituted soil) in the $\ln p^{\prime}-v$ plane (where $v=$ specific volume). Eq. (4) is of the same form as the equivalent hardening law in MCC and S-CLAY1, but with $p_{m}^{\prime}$ replaced by $p_{m i}^{\prime}$ and $\lambda$ replaced by $\lambda_{i}$.

The second hardening law (the rotational hardening law) describes the change of orientation of the yield surface with plastic straining (Wheeler et al. 2003)

$$
d \boldsymbol{\alpha}_{d}=\omega\left(\left[\frac{3 \boldsymbol{\eta}}{4}-\boldsymbol{\alpha}_{d}\right]\left\langle d \varepsilon_{v}^{p}\right\rangle+\omega_{d}\left[\frac{\boldsymbol{\eta}}{3}-\boldsymbol{\alpha}_{d}\right] d \varepsilon_{d}^{p}\right)
$$

where $\boldsymbol{\eta}=\boldsymbol{\sigma}_{d} / p^{\prime} ; d \varepsilon_{d}^{p}=$ increment of plastic deviatoric strain; and $\omega$ and $\omega_{d}=$ additional soil constants. The soil constant $\omega_{d}$ controls the relative effectiveness of plastic shear strains and plastic volumetric strains in setting the overall instantaneous target values for the components of $\boldsymbol{\alpha}_{d}$, whereas the soil constant $\omega$ controls the absolute rate of rotation of the yield surface toward the current target values of the components of $\boldsymbol{\alpha}_{d}$ (see Wheeler et al. 2003 for details). 

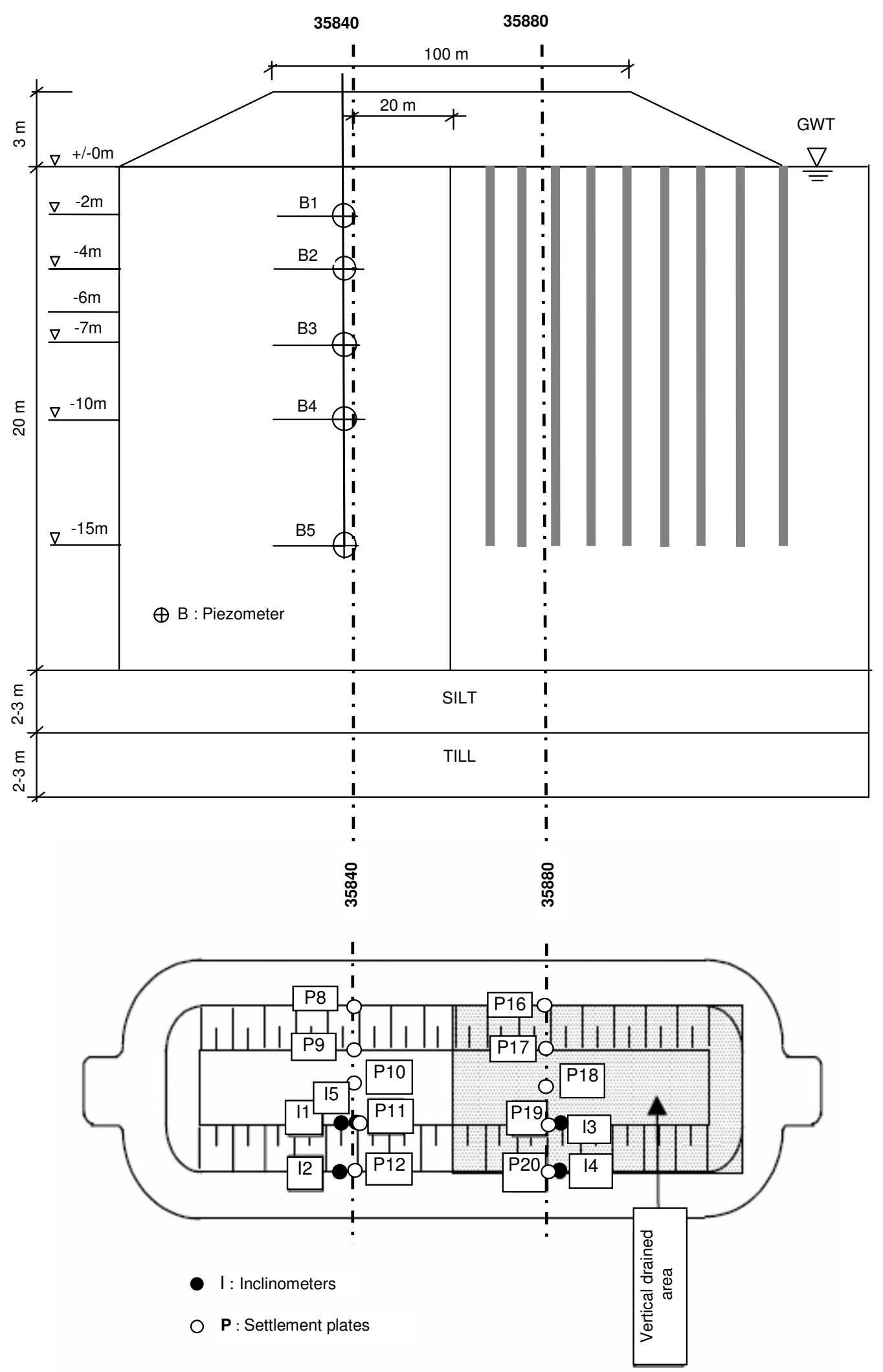

Fig. 3. Layout of some instrumentation at Haarajoki test embankment

The third hardening law in S-CLAY1S (the destructuration law) describes the degradation of bonding with plastic straining. It is similar in form to the rotational hardening law [Eq. (5)], except that both plastic volumetric strains and plastic shear strains (whether positive or negative) tend to decrease the value of the bonding parameter $\chi$ toward a target value of zero

$$
d \chi=\xi\left([0-\chi]\left|d \varepsilon_{v}^{p}\right|+\xi_{d}[0-\chi] d \varepsilon_{d}^{p}\right)=-\xi \chi\left(\left|d \varepsilon_{v}^{p}\right|+\xi_{d} d \varepsilon_{d}^{p}\right)
$$

where $\xi$ and $\xi_{d}=$ additional soil constants. Parameter $\xi$ controls the absolute rate of destructuration, and parameter $\xi_{d}$ controls the 
Table 1. Depths and Locations of Instruments under Haarajoki Test Embankment

\begin{tabular}{lccc}
\hline Instruments & Chainage & $\begin{array}{c}\text { Location (from } \\
\text { centerline) }\end{array}$ & $\begin{array}{c}\text { Depth } \\
(\mathrm{m})\end{array}$ \\
\hline Settlement plates & & & \\
P8 & 35840 & 9 m left & - \\
P9 & 35840 & 4 m left & - \\
P10 & 35840 & Centerline & - \\
P11 & 35840 & 4 m right & - \\
P12 & 35840 & 9 m right & - \\
P16 & 35880 & 9 m left & - \\
P17 & 35880 & 4 m left & - \\
P18 & 35880 & Centerline & - \\
P19 & 35880 & 4 m right & - \\
P20 & 35880 & 9 m right & - \\
Piezometer tips & & & \\
B1 & 35837 & Centerline & 2 \\
B2 & 35837 & Centerline & 4 \\
B3 & 35837 & Centerline & 7 \\
B4 & 35837 & Centerline & 10 \\
B5 & 35837 & Centerline & 15 \\
Inclinometers & & & - \\
I1 & 35838 & 4 m right & - \\
I2 & 35838 & 9 m right & - \\
I3 & 35882 & 4 m right & - \\
I4 & 35882 & 9 m right & - \\
I5 & 35838 & 4 m right & - \\
\hline
\end{tabular}

relative effectiveness of plastic deviatoric strains and plastic volumetric strains in destroying the bonding (see Koskinen et al. 2002a for details). Theoretically, as pointed out in Zentar et al. (2002), a monotonic reduction in $\chi$ implied by the hardening law [Eq. (6)] can sometimes result in reduction of $p_{m}^{\prime}$ during hardening for certain combinations of parameters $\xi$, $\xi_{d}$, and $\chi$. As a result, the peak undrained shear strength of the natural soil may actually be predicted to decrease during consolidation. There is field evidence for such behavior on a moderately sensitive Finnish clay, as discussed in Karstunen et al. (2005).

By setting the initial value of the state parameter $\chi$ to zero and using an apparent value of $\lambda$ (determined from an oedometer test on a natural clay sample), instead of the intrinsic value $\lambda_{i}$ of a reconstituted clay, S-CLAY1S reduces to the S-CLAY1 model that accounts for plastic anisotropy only. Furthermore, if in addition the initial value of the state parameter $\alpha$ (used for calculating the initial values of the components of the fabric tensor) and the value of the soil constant $\omega$ are set to zero, the model ultimately reduces to the isotropic modified cam clay (MCC) model.

\section{Haarajoki Test Embankment}

In 1997 the Finnish National Road Administration organized an international competition to predict the stress-strain behavior of a road embankment in Haarajoki, Finland. The embankment is founded on soft soil deposits which are typical for the region (FinnRA 1997), and can be characterized by a high degree of anisotropy and natural interparticle bonding, which reflect in geotechnical properties, such as the permeability, stress-strain relationship, and shear strength. Half of the embankment is constructed on an area improved with prefabricated vertical
Table 2. Haarajoki Test Embankment; Initial Values for State Parameters

\begin{tabular}{lccccr}
\hline Layer & Depth & $e_{0}$ & POP & $\alpha_{0}$ & $\chi_{0}$ \\
\hline 1 & $0.0-1.0$ & 1.4 & 76.5 & 0.58 & 4 \\
2 & $1.0-2.0$ & 1.4 & 60.0 & 0.58 & 4 \\
$3 \mathrm{a}$ & $2.0-3.0$ & 2.9 & 38.0 & 0.44 & 22 \\
$3 \mathrm{~b}$ & $3.0-4.0$ & 2.9 & 34.0 & 0.44 & 22 \\
$3 \mathrm{c}$ & $4.0-5.0$ & 2.9 & 30.0 & 0.44 & 22 \\
4 & $5.0-7.0$ & 2.8 & 24.0 & 0.42 & 30 \\
5 & $7.0-10.0$ & 2.3 & 21.0 & 0.41 & 45 \\
6 & $10.0-12.0$ & 2.2 & 28.5 & 0.41 & 45 \\
7 & $12.0-15.0$ & 2.2 & 33.5 & 0.44 & 45 \\
8 & $15.0-18.0$ & 2.0 & 17.0 & 0.58 & 45 \\
9 & $18.0-22.0$ & 1.4 & 1.0 & 0.58 & 45 \\
\hline
\end{tabular}

drains and the other half is constructed on natural deposits without any additional ground improvement. The data concerning site investigation and results of the associated laboratory tests and field monitoring data provided by FinnRA (1997) are very useful for the validation of different constitutive models and methods of analyses. Results of finite-element studies of the embankments have been published, by Aalto (1998), Näätänen et al. (1998), Cudny and Neher (2003), and most recently by Zhou and Yin (2004). The results of the competition to calculate the settlement of the embankment have been summarized in Lojander and Vepsäläinen (2001). The analyses by Aalto (1998) and Näätänen et al. (1998) were small strain analyses which assumed the soil to be isotropic, similarly to Zhou and Yin (2004) who also accounted for creep. Cundy and Neher (2003) utilized the so-called multilaminate framework to represent the soft soil. Their model accounted for anisotropy and destructuration via directionally distributed overconsolidation. This approach is, however, rather complex and difficult to justify, and furthermore the multilaminate models are computationally demanding and difficult to validate experimentally. In this paper the phenomena of anisotropy and destructuration are represented via the S-CLAY1S model, which is relatively easy to understand and, most importantly, experimentally validated for a number of natural clays (Koskinen et al. 2002a; Zentar et al. 2002; Karstunen and Koskinen 2004).

\section{Geometry and Ground Conditions}

The longitudinal profile and the cross section of Haarajoki test embankment are shown in Fig. 2. The embankment is $2.9 \mathrm{~m}$ high and $100 \mathrm{~m}$ long, $8 \mathrm{~m}$ wide, and the slopes have a gradient of 1:2. The embankment itself was constructed in $0.5 \mathrm{~m}$ thick layers and each layer was applied and compacted within 2 days. In the improved area the vertical drains were installed in a regular pattern with $1 \mathrm{~m}$ spacing before embankment construction. Numerous measuring devices (settlement plates, piezometers, inclinometers, pressure cells) were installed under the test embankment for monitoring the vertical and lateral displacements and the pore pressures. The layout of some of these instruments is presented in Fig. 3 and the depths and locations of these instruments are summarized in Table 1.

Haarajoki test embankment is founded on a $2 \mathrm{~m}$ thick dry crust layer overlying a $22.2 \mathrm{~m}$ thick soft clay deposit. The layers below the soft clay consist of silt and till material, based on cone penetration tests (CPTs), and can be considered as permeable (FinnRA 1997). The groundwater table is at the ground surface. The subsoil is divided into nine sublayers with different compressibility parameters and overconsolidation ratios. The water 
Table 3. Haarajoki Test Embankment; Values for MCC Soil Constants

\begin{tabular}{|c|c|c|c|c|c|c|}
\hline Layer & $\gamma$ & $\phi^{\prime}$ & $v^{\prime}$ & $\kappa$ & $\lambda$ & $M$ \\
\hline 1 & 17.0 & 36.9 & 0.35 & 0.006 & 0.12 & 1.50 \\
\hline 2 & 17.0 & 36.9 & 0.35 & 0.009 & 0.21 & 1.50 \\
\hline $3 a$ & 14.0 & 28.8 & 0.18 & 0.033 & 1.33 & 1.15 \\
\hline $3 b$ & 14.0 & 28.8 & 0.18 & 0.033 & 1.33 & 1.15 \\
\hline $3 c$ & 14.0 & 28.8 & 0.18 & 0.033 & 1.33 & 1.15 \\
\hline 4 & 14.0 & 27.7 & 0.10 & 0.037 & 0.96 & 1.10 \\
\hline 5 & 15.0 & 27.0 & 0.10 & 0.026 & 0.65 & 1.07 \\
\hline 6 & 15.0 & 27.0 & 0.28 & 0.031 & 1.16 & 1.07 \\
\hline 7 & 15.0 & 28.8 & 0.28 & 0.033 & 1.06 & 1.15 \\
\hline 8 & 16.0 & 36.9 & 0.28 & 0.026 & 0.45 & 1.50 \\
\hline 9 & 17.0 & 36.9 & 0.28 & 0.009 & 0.10 & 1.50 \\
\hline
\end{tabular}

content of the soft clay layer varies between 75 and $112 \%$ depending on the depth, and is almost the same as, or greater than, the liquid limit. The bulk density varies from 14 to $17 \mathrm{kN} / \mathrm{m}^{3}$ and specific gravity varies from 2.73 to 2.79 . The undrained (undisturbed) shear strength was determined by fall cone tests and field vane tests to be between 15 and $42 \mathrm{kN} / \mathrm{m}^{2}$ (FinnRA 1997). The Haarajoki deposits can be characterized as a sensitive anisotropic soft soil with sensitivity values (determined with fall cones tests) between 20 and 55. The organic content is between 1.4 and $2.2 \%$ at a depth of 3-13 m. Some typical characteristics of the deposits are shown in Fig. 4.

\section{Input Data for Numerical Analyses}

The embankment, which was made of granular fill, was modeled with a simple Mohr-Coulomb model assuming the following material parameters: $E^{\prime}=40,000 \mathrm{kN} / \mathrm{m}^{2}, v^{\prime}=0.35, \phi^{\prime}=40^{\circ}, \psi^{\prime}=0^{\circ}$, $c^{\prime}=2 \mathrm{kN} / \mathrm{m}^{2}$, and $\gamma=21 \mathrm{kN} / \mathrm{m}^{3}$ (where $E^{\prime}=$ Young's modulus; $\nu^{\prime}=$ Poisson's ratio; $\phi^{\prime}=$ friction angle $; \psi^{\prime}=$ dilatancy angle; and $\gamma=$ unit weight of the embankment material). The problem is dominated by the soft clay response and is hence rather insensitive to the embankment parameters.

The soft clay deposit was modeled as a lightly overconsolidated soft clay with vertical preconsolidation pressures varying with the depth as shown in Fig. 5 and Table 2. In the analyses the preconsolidation is modeled via vertical preoverburden pressure $(\mathrm{POP})=\sigma_{p}^{\prime}-\sigma_{v 0^{\prime}}\left(\right.$ where $\sigma_{v 0^{\prime}}$ and $\sigma_{p}^{\prime}$ are, respectively, the in situ value and maximum past value of the vertical effective stress). The in situ stresses were calculated by assuming a horizontal effective stress distribution, using $K_{0}$ values estimated with the equation $K_{0}=\left(1-\sin \phi^{\prime}\right) \mathrm{OCR}^{\sin \phi^{\prime}}$ (Mayne and Kulhawy 1982), where $\phi^{\prime}=$ critical state friction angle in triaxial compression and $\mathrm{OCR}=$ vertical overconsolidation ratio $\left(\mathrm{OCR}=\sigma_{p}^{\prime} / \sigma_{v 0^{\prime}}\right)$. The values of the input parameters and state variables for the models are listed in Tables 2-4. The values of soil parameters were estimated for each layer based on laboratory results provided by FinnRA (1997) using the best practice for the determination of model and state parameters for the S-CLAY1S model and its simplifications (i.e., S-CLAY1 and MCC). Due to natural variability, there was some scatter in the values and for each layer average values have been chosen. The values of permeability used for calculations were reported by Näätänen et al. (1998) based on vertical and horizontal constant rate of strain (CRS) oedometer tests. In the finite-element analyses, the decrease in the permeability as the void ratio decreases was taken into account using the formula by Taylor (1948)

$$
\log \left(\frac{k}{k_{0}}\right)=\frac{\Delta e}{c_{k}}
$$

where $\Delta e=$ change in void ratio; $k=$ soil permeability in the calculation step; $k_{0}=$ initial value of the permeability; and $c_{k}=$ permeability change index. It was assumed that $c_{k}=0.5 e_{0}$ in the calculations (Tavenas et al. 1983). The use of the S-CLAY1 model requires values of six soil constants $\left(\lambda, \kappa, v^{\prime}, M, \omega\right.$, and $\left.\omega_{d}\right)$ and information on initial state (initial values for void ratio $e_{0}$, $\alpha_{0}$, and $p_{m}^{\prime}$ ). The values of $\kappa$ and $\lambda$ were determined from oedometer test results. The values for the initial inclination $\alpha_{0}$ of the yield surface and parameter $\omega_{d}$ were determined following the procedure described by Wheeler et al. (2003), using $K_{0}^{\mathrm{NC}}$ values corresponding to Jaky's simplified formula. The values of $\omega$ were estimated based on apparent values of $\lambda$, as suggested by Zentar et al. (2002). The use of the S-CLAY1S model requires, additionally, values for the two destructuration parameters $\left(\xi\right.$ and $\left.\xi_{d}\right)$ and information on the initial amount of bonding $\chi_{0}$. The values of $\lambda_{i}$ need to be measured from oedometer tests on reconstituted samples. In the absence of these tests, $\lambda_{i}$ values were estimated throughout the deposit assuming similar $\lambda / \lambda_{i}$ ratios to other Finnish clays, and similarly, past experience on Finnish clays was used in fixing the values for parameters $\xi$ and $\xi_{d}$ that control the rate of degradation of bonding. The initial values of $\chi_{0}$ were estimated based on sensitivity, as suggested in Koskinen et al. (2002a). Therefore, in the following simulations, it is possible to do quantitative comparisons between the isotropic MCC model and the anisotropic S-CLAY1 model, but the comparisons between these models and the S-CLAY1S model are generally qualitative rather than quantitative, given not enough data were available for determination of the key constants controlling the rate of destructuration.

\section{Numerical Analyses and Comparisons with Observations}

In order to investigate the influence of anisotropy and destructuration on the behavior of an embankment on Haarajoki deposits, the construction and consolidation of Haarajoki test embankment on soft soils with and without vertical drains were simulated with different constitutive models (MCC, S-CLAY1, and S-CLAY1S) using PLAXIS 2D Version 8.2 (Brinkgreve 2002). These constitutive models have been implemented in the finite-element program as user-defined models by Wiltafsky (2003). The results of the numerical analyses were compared with the field measure- 


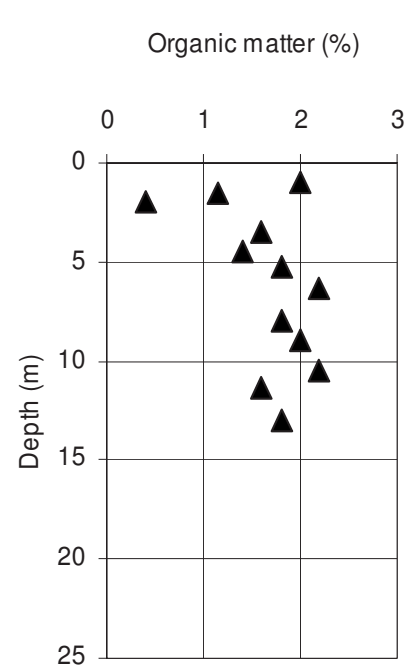

(a)

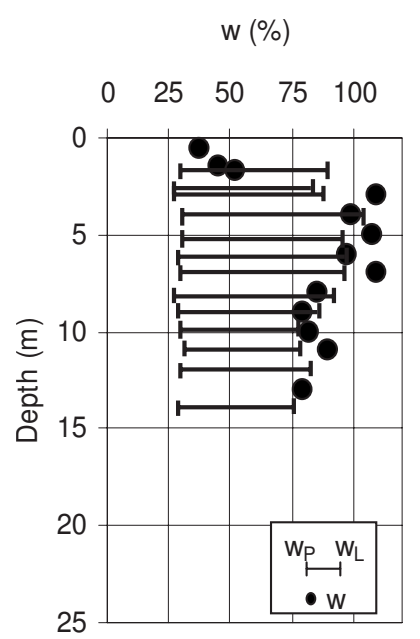

(d)

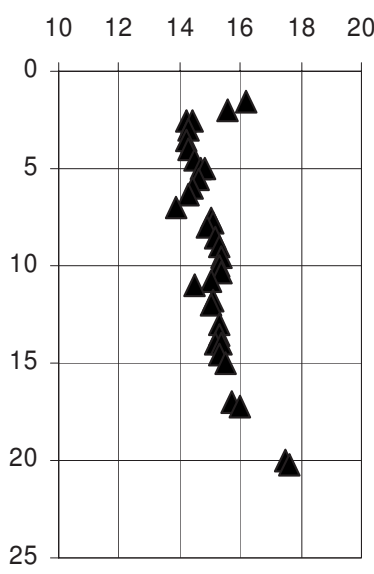

(b)

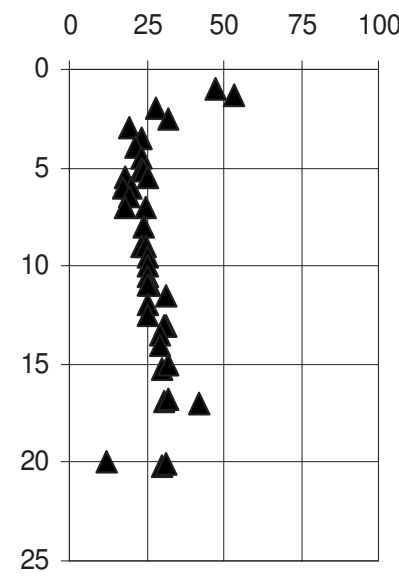

(c)

Sensitivity (-)

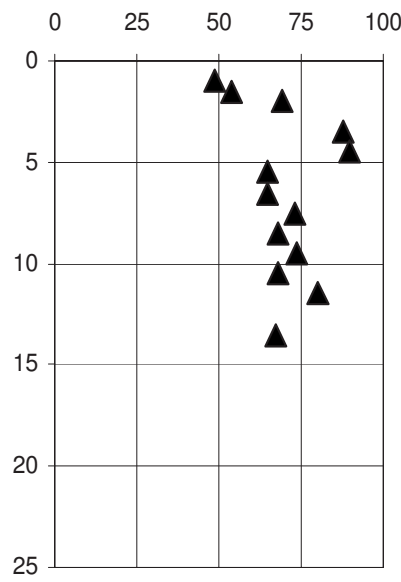

(e)

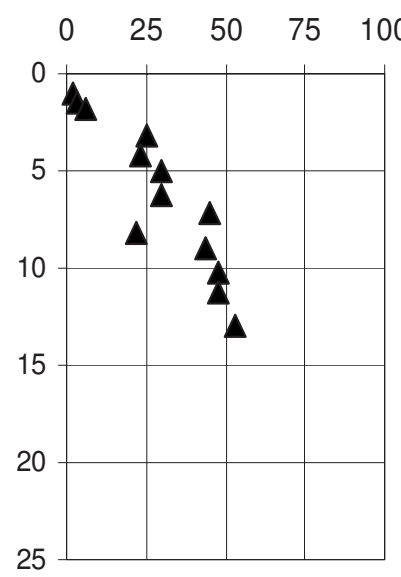

(f)

Fig. 4. Typical soil characteristic of Haarajoki deposit

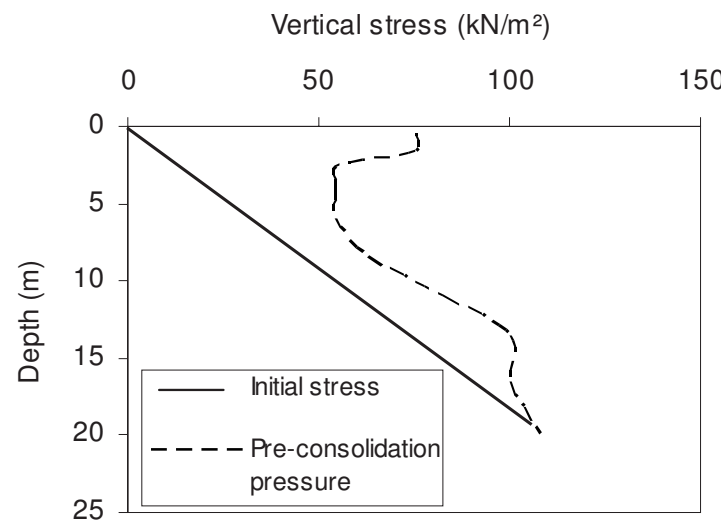

Fig. 5. Haarajoki deposit; in-situ vertical effective stresses and preconsolidation pressures
Table 4. Haarajoki Test Embankment; Values for Additional Soil Constants for S-CLAY1 and S-CLAY1S

\begin{tabular}{lccccc}
\hline Layer & $\omega_{d}$ & $\omega$ & $\lambda_{i}$ & $\xi$ & $\xi_{d}$ \\
\hline 1 & 1.00 & 50 & 0.04 & 8 & 0.2 \\
2 & 1.00 & 50 & 0.06 & 8 & 0.2 \\
$3 \mathrm{a}$ & 0.70 & 20 & 0.38 & 8 & 0.2 \\
$3 \mathrm{~b}$ & 0.70 & 20 & 0.38 & 8 & 0.2 \\
$3 \mathrm{c}$ & 0.70 & 20 & 0.38 & 8 & 0.2 \\
4 & 0.64 & 20 & 0.27 & 8 & 0.2 \\
5 & 0.60 & 20 & 0.19 & 8 & 0.2 \\
6 & 0.60 & 20 & 0.33 & 8 & 0.2 \\
7 & 0.70 & 20 & 0.30 & 8 & 0.2 \\
8 & 1.00 & 20 & 0.13 & 8 & 0.2 \\
9 & 1.00 & 20 & 0.03 & 8 & 0.2 \\
\hline
\end{tabular}




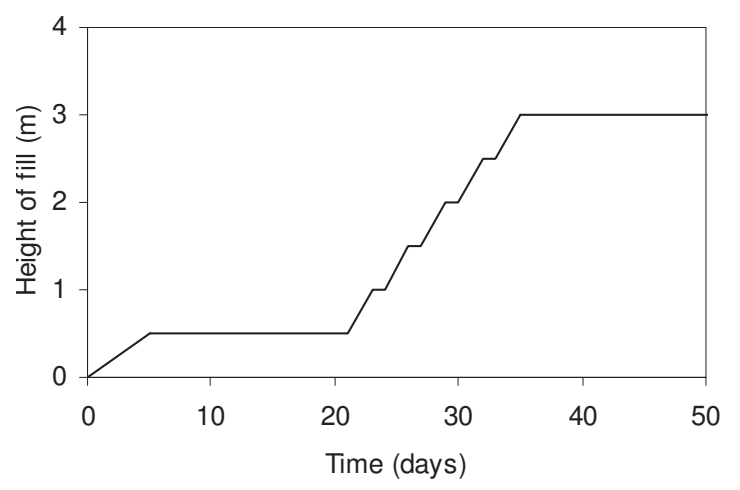

Fig. 6. Haarajoki test embankment; construction schedule

ments. A cross section of the embankment built on soft clay without vertical drains (Cross Section 35840) was firstly simulated and then a cross section within the vertically drained area (Cross Section 35880) was simulated.

\section{Cross Section 35840}

The Cross Section 35840 is situated on the natural deposits without any ground improvement. The test embankment was assumed symmetric and only half of the embankment is considered in the finite-element analyses. The plane strain condition and six-noded triangular elements were used and all simulations were done as large strain analyses. A finite-element mesh with 833 elements is used to model the subsoil and the embankment. The groundwater table is located at the ground surface. The lateral boundaries are restrained horizontally, and the bottom boundary is restrained in both directions. Drainage boundaries are assumed to be at the ground surface and at the bottom of the mesh, whereas the lateral boundaries are closed. The embankment construction consists of two phases: first, the embankment loading is applied under undrained conditions, assuming the embankment to be drained material and next, a consolidation phase is simulated via fully coupled consolidation analysis. The construction of Haarajoki embankment was done in $0.5 \mathrm{~m}$ layers, each taking 2 days, while the foundation layer was constructed in 5 days, and the real construction schedule has been simulated in the calculation (Fig. 6). After the construction of each layer a consolidation phase is introduced to allow the excess pore pressures to dissipate. Hence, a total of 12 calculation phases were defined in the analyses. The construction of embankment was completed in 35 days. After construction of the last layer, the calculations have been taken until the excess pore pressure had dissipated to a residual value of $1 \mathrm{kPa}$ to determine the final consolidation settlement. Mesh sensitivity studies were done to confirm that the mesh was dense enough to give accurate results for all of the constitutive models concerned.

The observed and predicted vertical settlements versus time at a node directly under the centerline and the crest of the embankment are presented in Fig. 7. Differences between the three models are relatively minor immediately after construction of the embankment, but become significant during consolidation. The measured settlement underneath the centerline of the embankment is $0.46 \mathrm{~m}$ after about 5 years of consolidation. The MCC model predicts a vertical displacement of about $0.33 \mathrm{~m}$ after 5 years of consolidation underneath the centerline of the embankment, while the S-CLAY1 and S-CLAY1S models predict vertical displacements of about 0.43 and $0.49 \mathrm{~m}$, respectively [Fig. 7(a)]. The final value of settlement underneath the crest, corresponding to about

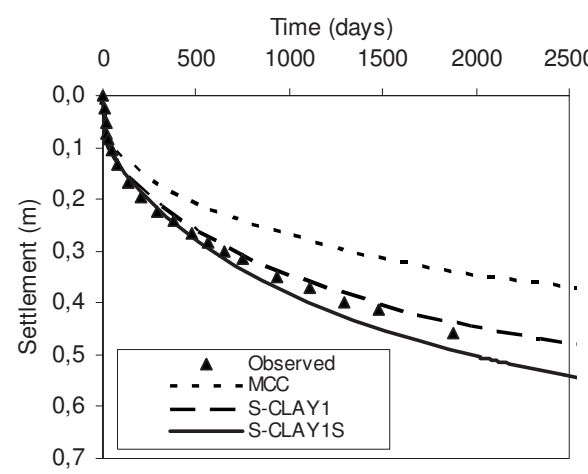

(a)

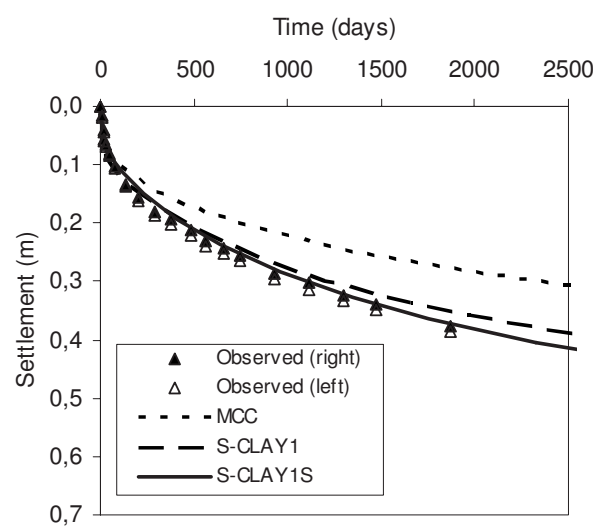

(b)

Fig. 7. Haarajoki test embankment; Cross Section 35840; timesettlement curves: (a) center line; (b) $4 \mathrm{~m}$ from center line (under crest)

5 years of consolidation, is measured to be $0.39 \mathrm{~m}$. The vertical displacements underneath the crest are predicted by S-CLAY1 and S-CLAY1S models to be $0.36 \mathrm{~m}$ and $0.38 \mathrm{~m}$, respectively while the MCC model predicts as about $0.28 \mathrm{~m}$ after about 5 years of consolidation [Fig. 7(b)]. The predictions of the vertical displacements by the two anisotropic models (S-CLAY1 and S-CLAY1S) are in good agreement with field observations. The isotropic MCC model predicts notably smaller settlements than the observed ones. The S-CLAY1S model predicts marginally larger vertical settlements than the S-CLAY1 model. Both the calculated and observed time-settlement curves suggest that the primary consolidation is still continuing after 2,000 days, which corresponds to the last measurement data available.

The predicted surface settlements corresponding to a time immediately after construction and after 5 years of consolidation are shown in Fig. 8. The measurements demonstrate that assuming symmetry was justified. All models predict small amounts of surface heave outside the embankment immediately after construction [Fig. 8(a)] and a maximum vertical settlement underneath the centerline of the embankment. The maximum vertical settlement measured underneath the centerline of the embankment is about $0.46 \mathrm{~m}$ after 5 years of consolidation. The MCC model predicts a vertical displacement of about $0.33 \mathrm{~m}$ after 5 years of consolidation, while the S-CLAY1 and S-CLAY1S models predict vertical displacements of about 0.43 and $0.49 \mathrm{~m}$, respectively [Fig. 8(b)]. Again it can be seen that both anisotropic models are in good agreement with the observed surface settlements.

The vertical displacements at different depths underneath the centerline of the embankment predicted by three constitutive 


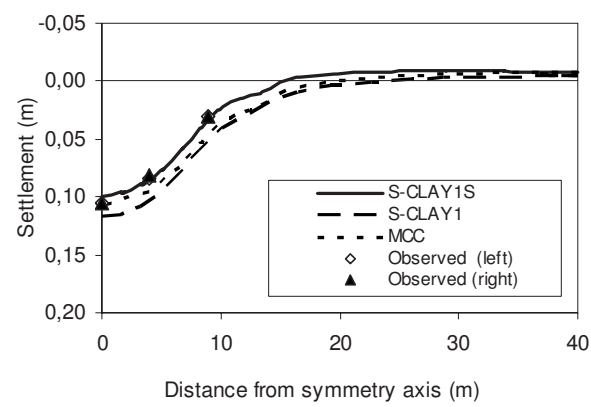

(a)

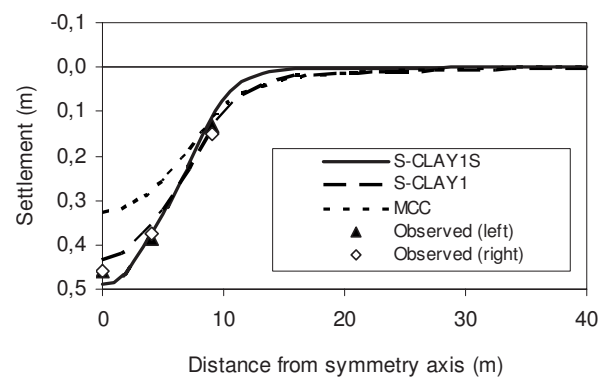

(b)

Fig. 8. Haarajoki test embankment; Cross Section 35840; surface settlements: (a) immediately after construction; (b) after 5 years of consolidation

models are presented in Fig. 9 against time. Unfortunately, no extensometer results were available for comparison. SCLAY1S predicts larger vertical settlements than the S-CLAY1 and MCC models within the dry crust layer. At a depth of $2 \mathrm{~m}$, the values of settlements obtained from the S-CLAY1 and S-CLAY1S models are very similar. However, the S-CLAY1 model predicts larger settlements than the S-CLAY1S and MCC models from a depth of $2 \mathrm{~m}$ downwards. This is due to the predicted rate of destructuration, which depends on the values assumed for soil constants $\lambda_{i}$, $\xi$, and $\xi_{d}$ (which were chosen based on experience rather than directly derived from laboratory data), the initial amount of bonding $\left(\chi_{0}\right)$, as well as the stress ratio. In the normally consolidated range, the predicted stress ratio depends on the input values for $M$ (or $\phi^{\prime}$ ) for the anisotropic S-CLAY models. For high stress ratio (low $K_{0}$ ), destructuration is rapid, and hence the values of apparent $\lambda$ are high and the settlements predicted by S-CLAY1S are large at shallow depths. For nearly isotropic stress paths, the destructuration would be slow and the apparent values of $\lambda$ are rather low. In the case of Haarajoki embankment, the value of normally consolidated $K_{0}$ increases with depth up to a depth of $12 \mathrm{~m}$. With the chosen set of parameters, the effect of anisotropy overall seems to be more dominant than destructuration (see Fig. 7), but as demonstrated in Fig. 7, this is not necessarily true with depth. It should be noted again that the results by S-CLAY1S in Fig. 9 are qualitative rather than quantitative but demonstrate the complex effect of destructuration on natural clays. Based on Fig. 9 , it would be good practice for any test embankments to have extensometers installed in order to be able to fully validate constitutive models.

The horizontal displacements predicted by the MCC, S-CLAY1, and S-CLAY1S models underneath the crest of the embankment ( $4 \mathrm{~m}$ from the centerline) after 1 and 3 years of consolidation are compared with the measured values in Figs. 10( $\mathrm{a}$ and $\mathrm{b}$ ). After 1 year of consolidation the predictions by the anisotropic models (S-CLAY1 and SCLAY1S) are closer to the measured results than the prediction by the MCC model. The horizontal displacements after 3 years of consolidation predicted by the SCLAY1 model are again in good agreement with the measured ones [Fig. 10(b)]. The MCC model underestimates the horizontal displacements up to a depth of $5 \mathrm{~m}$. The measured maximum horizontal displacement is about $0.076 \mathrm{~m}$ and it occurs at a depth of about $2.5 \mathrm{~m}$. The S-CLAY1 model predicts the maximum value as $0.067 \mathrm{~m}$, in contrast to $0.042 \mathrm{~m}$ by the MCC model. The scatter in the measurements in Fig. 10 is notable, in particular at great depths, and the reason for this is that the original inclinometer I1 was destroyed during construction, and I5 was later on added as a replacement. The values in Fig. 10 are the sum of I1 displacements at a particular time with $\mathrm{I} 5$ results. One may therefore question the reliability of the field measurements under the crest of the embankment. Fortunately these are not as apparent under the toe of the embankment. Fig. 11 shows a comparison of the measured horizontal displacements with the predicted horizontal displacements underneath the toe of the embankment (about $9 \mathrm{~m}$ from the centerline). The MCC model gives a marginally better prediction of horizontal displacements underneath the toe of the embankment than S-CLAY1, despite of the poor prediction of vertical displacements in Fig. 7. Again the measured maximum horizontal displacement occurs at a depth about $2.5 \mathrm{~m}$ and is about $0.062 \mathrm{~m}$. As seen from Figs. 10 and 11, the MCC model overall predicts lower values of horizontal displacements than the two anisotropic models and notably smaller vertical deformations (Fig. 7) than the anisotropic models. Consequently, the isotropic model predicts a much higher ratio of horizontal to vertical displacements than the anisotropic models. The depth of the maximum horizontal displacement was well predicted by all models considered. All models seem to overpredict the horizontal displacements between 5 and $15 \mathrm{~m}$ depths, and the measured horizontal displacements are very small, or approximately zero, after $15 \mathrm{~m}$ depth.

The predicted and measured excess pore pressure values at different depths under the centerline of the embankment are compared in Fig. 12. As expected, the excess pore pressures increase during the embankment construction and then gradually dissipate with time. The predicted excess pore pressures are in general higher than the measured ones. The calculated excess pore pressure values correspond quite well with the measurements at depths of 10 and $15 \mathrm{~m}$, while the predicted values at 4 and $7 \mathrm{~m}$ depths are greater than the measured values. This can be partly explained by the fact that the excess pore pressures are strongly influenced by the foundation soil permeability. The values of permeability used in the analyses were calculated directly from CRS oedometer test results. Laboratory tests normally underestimate the field values of permeability. The other reason for the discrepancies of predicted and measured excess pore pressures might be due to possible errors in measurements or their interpretation, and/or due to ignoring the effects of creep in the simulations.

\section{Cross Section 35880 (PVD Improved Area)}

Cross section 35880 is situated in the middle of the part of Haarajoki test embankment constructed on soft clay improved with PVDs (Fig. 2). The length of the vertical drains is $15 \mathrm{~m}$ and they were installed in a square grid with $1 \mathrm{~m}$ spacing underneath the embankment. The drain parameters relevant for the analysis are summarized in Table 5. The prefabricated drains have a typical rectangular cross section and were converted to be equivalent to a circular drain having a diameter $d_{w}$ of $67 \mathrm{~mm}$ based on "perimeter equivalence" proposed by Hansbo (1979) 

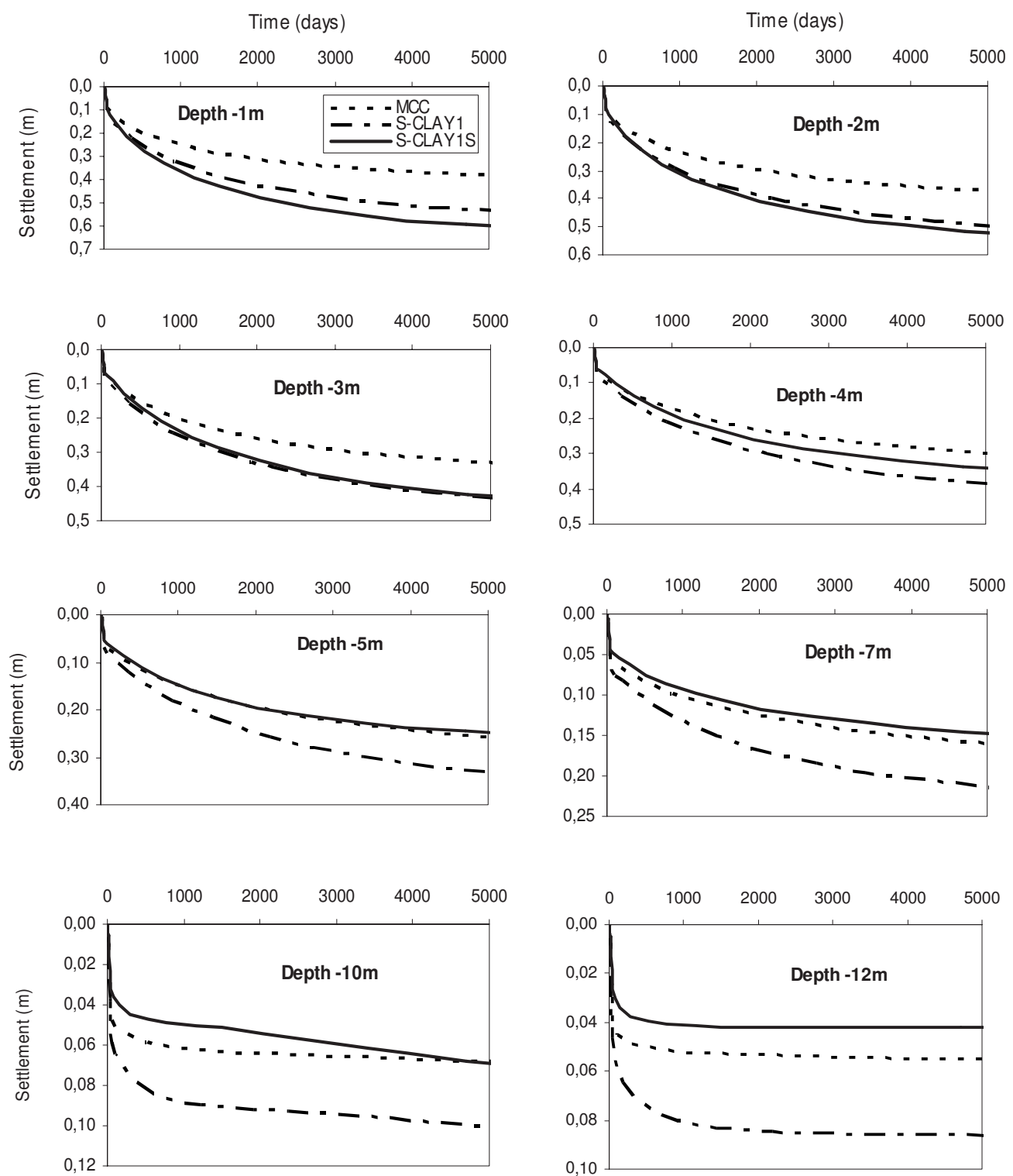

Fig. 9. Haarajoki test embankment; Cross Section 35840; vertical displacements at different depths underneath center line

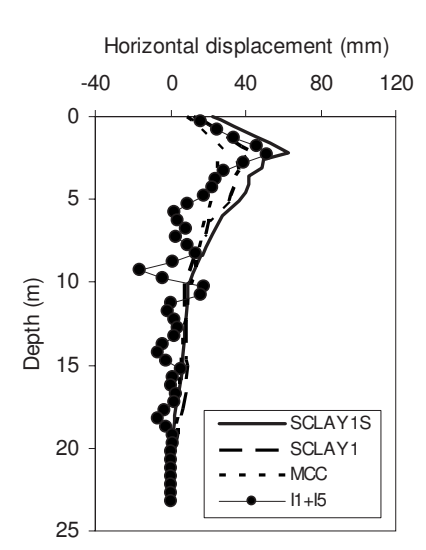

(a)

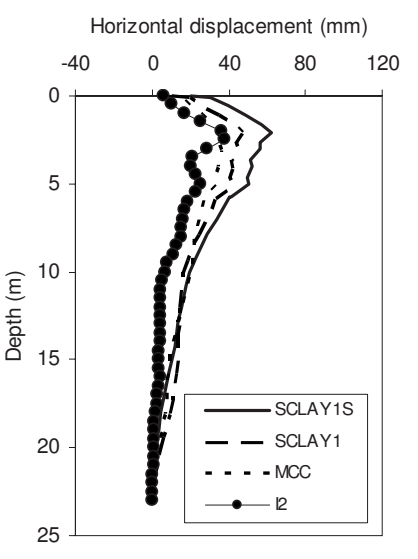

(a)

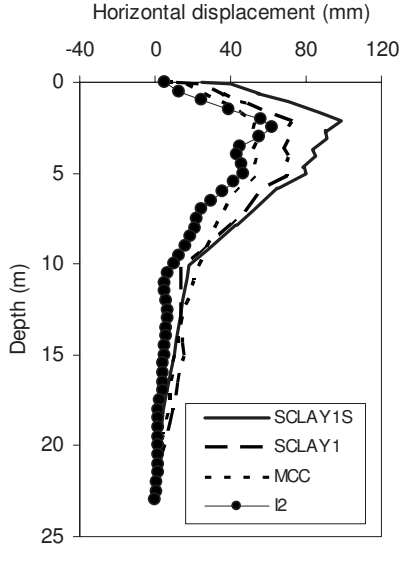

(b)
Fig. 10. Haarajoki test embankment; Cross Section 35840; horizontal displacements underneath crest of embankment: (a) after 1 year; (b) after 3 years
Fig. 11. Haarajoki test embankment; Cross Section 35840; horizontal displacements underneath toe of embankment: (a) after 1 year; (b) after 3 years 

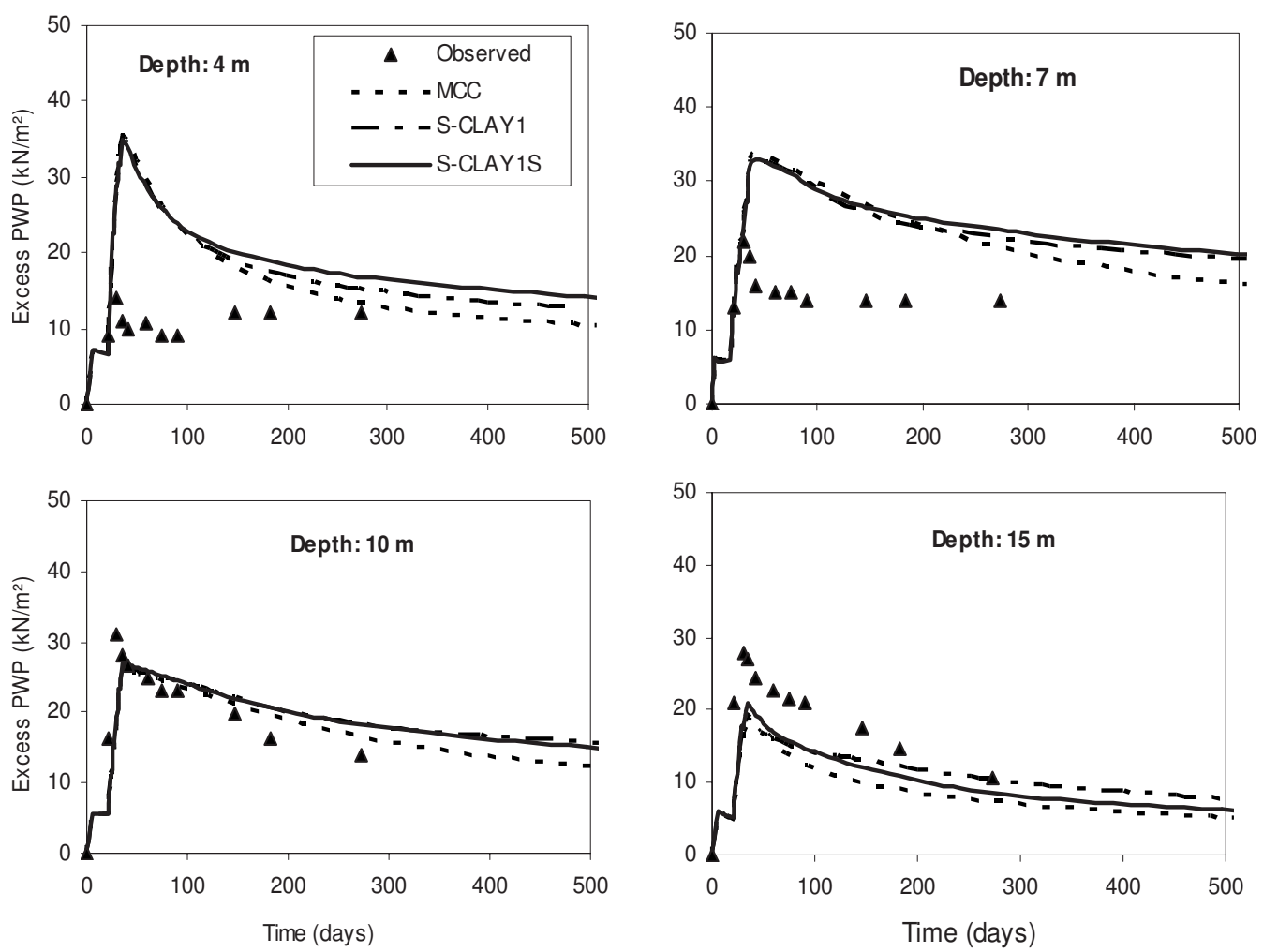

Fig. 12. Haarajoki test embankment; Cross Section 35840; excess pore pressures at different depths

$$
d_{w}=\frac{2(w+t)}{\pi}
$$

where $d_{w}=$ equivalent diameter of a drain; and $w$ and $t=$ width and thickness of the drain, respectively. In the field, the drain is installed by using a mandrel, which is pushed into the ground. Then the mandrel is withdrawn, leaving the drain in subsoil. This process creates a completely disturbed zone around the drain, called the smear zone. In the smear zone the compressibility, permeability, and the amount of bonding in structured soils are reduced by an unknown amount. The equivalent diameter of the mandrel $\left(d_{m}\right)$ is assumed to be $100 \mathrm{~mm}$. These values of $d_{m}$ and $d_{w}$ correspond to a value of $d_{m} / d_{w} \cong 1.5$. The effective diameter of a drain influence was taken to be $D_{e}=1.13 S$ for a square configuration (Rixner et al. 1986) where $S$ is the drain spacing.

A 3D multidrain analysis, with modeling drains and the surrounding smear zone with for each and every drain, is very sophisticated and requires large computational effort when applied to a real embankment project with a large number of PVDs. 2D finite-element analyses of embankments have commonly been conducted under plane strain conditions and, therefore, the conversion of axisymmetric vertical drains into an equivalent plane strain model is necessary. Analytical solutions already developed for consolidation of ground improved with vertical drains invari-

Table 5. Haarajoki Test Embankment: Drain Properties

\begin{tabular}{lc}
\hline Drain pattern & Square net \\
Model & SOLPACK C634 \\
Spacing $(S)$ & $1 \mathrm{~m}$ \\
Ave. width of drain $(w)$ & $98.7 \mathrm{~mm}$ \\
Thickness at $20 \mathrm{kPa}(t)$ & $6.83 \mathrm{~mm}$ \\
Discharge capacity, $q_{w}$ & $157 \mathrm{~m}^{3} /$ year \\
\hline
\end{tabular}

ably employ a unit cell model (Fig. 13). The theory for radial drainage consolidation has been considered by many researchers (Barron 1948; Hansbo 1981; Onoue 1988; Zeng and Xie 1989; Hird et al. 1992). Based on Hansbo's (1981) solution, Hird et al. (1992) showed that the average degree of consolidation $U$, at any depth and time in the two unit cells (axisymmetric and plane strain) were theoretically identical and the mapping can be achieved by any one of three methods: (1) geometric mappingthe drain spacing is matched while maintaining the same perme-

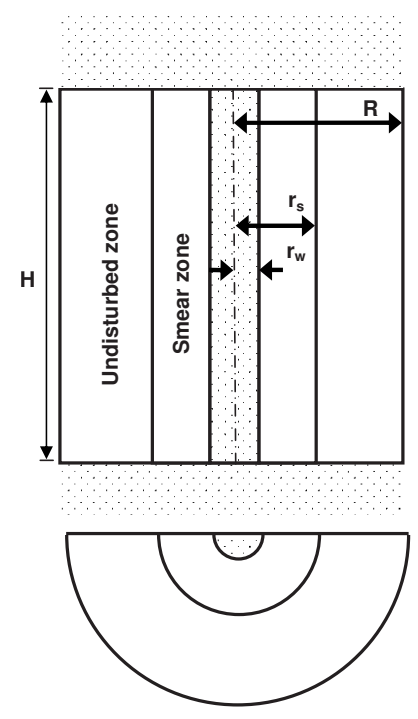

(a)
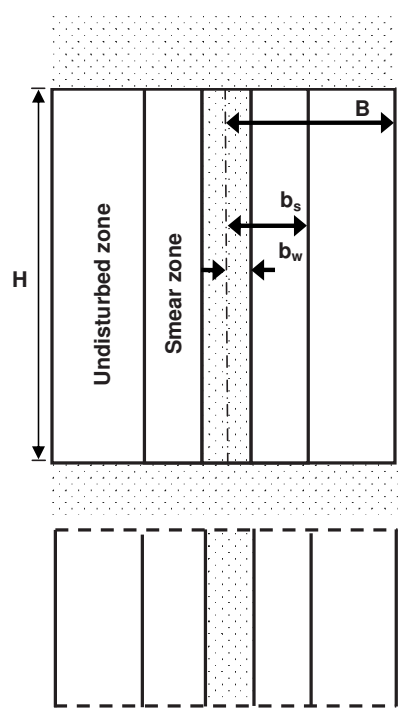

(b)

Fig. 13. Definition of symbols for unit cell analysis: (a) axisymmetric unit cell; (b) plane strain unit cell 
ability coefficient; (2) permeability mapping-coefficient of permeability is matched while keeping the same drain spacing; and (3) combination of (1) and (2), with the plane strain permeability calculated for a convenient drain spacing. The latter is referred to as combined mapping. In this approach, a value of $B$ (half width of unit cell) is preselected and the equivalent permeability $k_{p l}$ is calculated via the following equation (Hird et al. 1992):

$$
\frac{k_{p i}}{k_{a x}}=\frac{2 B^{2}}{3 R^{2}\left[\ln \left(\frac{R}{r_{s}}\right)+\left(\frac{k_{a x}}{k_{s}}\right) \ln \left(\frac{r_{s}}{r_{w}}\right)-\left(\frac{3}{4}\right)\right]}
$$

where $B=$ half width of the plane strain unit cell; $R, r_{w}$, and $r_{s}$ $=$ radius of the axisymmetric unit cell, drain, and smear zone, respectively; and $k_{h}$ and $k_{s}=$ horizontal permeability of the undisturbed and smeared soil, respectively. The excess pore pressures in the equivalent plane strain model are not comparable at corresponding points with those by the axisymmetric model since either the geometry or soil permeabilities are changed in the mapping procedures.

The mapping procedure above applies for a unit cell condition (i.e., a single drain surrounded by a soil cylinder) assuming an elastic soil and constant permeability in the absence of lateral movements. Such restrictive conditions do not represent real soft soil behavior, and ignore key phenomena, such as nonlinear stiffness, anisotropic behavior and varying permeability. Therefore, the first step was to investigate if the mapping methods by Hird et al. (1992) can be used with advanced constitutive models, such as MCC, S-CLAY1, and S-CLAY1S. Yildiz et al. (2006) conducted numerical simulations on a unit cell model using the soil parameters and layering given in Tables 2-4. Fig. 13 schematically shows an axisymmetric unit cell with the total radius, $R$ and its equivalent plane strain unit cell with half width, $B$. In Haarajoki embankment the length of the vertical drains $(L)$ is $15 \mathrm{~m}$ and only a single drain was modeled in the analyses. The equivalent drain radius $\left(r_{w}\right)$ and unit cell radius $(R)$ were calculated as 0.034 and $0.565 \mathrm{~m}$, respectively. The unit cell analysis based on perfect drain conditions (no smear effect and well resistance) was performed first. According to Yildiz et al. (2006), all mapping procedures produced effectively identical settlement response. However, the rate of consolidation in the equivalent plane strain analyses is predicted to be marginally faster than that in the corresponding axisymmetric analysis. The error was different from model to model, and varied during consolidation from 0.06 to $9 \%$, being the largest after a few months of consolidation. The error was larger with the anisotropic models than the isotropic one.

An uncertainty in the numerical analysis of vertical drains relates to the smear zone around vertical drains and the well resistance. Well resistance refers to the finite permeability of the vertical drain with respect to the soil. The limited discharge capacity of drains can cause a serious delay in the consolidation process. In general, laboratory and field data indicate that the discharge capacities of most commercial PVDs have little influence on the consolidation rate of clay, especially for drains that are not too long (Indraratna et al., 1994). For values of $q_{\mathrm{w}}$ $>100-150 \mathrm{~m}^{3}$ /year (in the field) and where drains are shorter than $30 \mathrm{~m}$, there should be no significant increase in the consolidation time. According to Hansbo (1997), the discharge capacity of modern prefabricated vertical drains is considered to be high enough $\left(q_{w}>150 \mathrm{~m}^{3} /\right.$ year $)$ and the effect of well resistance can be ignored in the design. Hence, the effect of well resistance is neglected in the numerical analyses.
In the field, the installation process causes significant disturbance in the soil surrounding the mandrel. The permeability of soil in the disturbed zone is reduced, because the structure of the soil is destroyed by mechanical disturbance (Zhou et al. 1999) and other properties may also be influenced. Hence, the smear effect must be taken into consideration in the finite-element analyses. Two key parameters are necessary to characterize the smear effect, namely: (1) the diameter of the smear zone $\left(d_{s}\right)$; and (2) the horizontal permeability in the smear zone $\left(k_{s}\right)$ (Chai and Miura 1999). The extent and permeability of the smear zone are difficult to determine from laboratory tests, and so far there is no comprehensive or standard method to measure them. Furthermore, none of the laboratory studies has considered structured soils. The effects have been found to vary with the installation procedure, size, and shape of the mandrel and soil microfabric (Hawlader et al. 2002). Several researchers have investigated these factors (Jamiolkowski and Lancellotta 1981; Madhav et al. 1993; Bergado et al. 1993; Indraratna and Redana 1998). Indraratna and Redana (1998) estimated that the radius of smear zone to be a factor of 4-5 times the radius of the mandrel $\left(r_{m}\right)$ based on laboratory model tests on reconstituted soils. Chai and Miura (1999) suggested a value of $d_{s}=3 d_{m}$, while the studies of Bo et al. (2000) and Xiao (2001) indicate that the smear zone can be as large as four times the size of the mandrel, or 5-8 times the equivalent diameter of drain. For analysis purposes, a constant permeability, which is less than the permeability of the undisturbed soil, is usually adopted for the smear zone. Tests performed on the soil specimens collected from a field located at different distances from the vertical drain have shown that the permeability of the soil near the drain is reduced to about one fifth the permeability of the undisturbed soil (Madhav et al. 1993). According to Bergado et al. (1993) the ratio of $k_{h} / k_{s}$ was found to be between 5 and 20 for Bangkok clay based on field full-scale tests. It is seen that there is no general agreement in the literature, and the size of smear zone and its permeability are still not exactly known.

Haarajoki deposits can be characterized as a very sensitive anisotropic soft clay. The water content is often higher than the liquid limit. Hence, considerable disturbance is expected in the subsoil during the installation of vertical drains. However, there is no test data available relating to the key parameters and the smear zone $\left(d_{s} / d_{m}\right.$ and $\left.k_{h} / k_{s}\right)$ for this particular soil. In the following analysis, these parameters were determined from the backcalculations. The ratio of $d_{s} / d_{m}$ or $k_{h} / k_{s}$ were varied to show how well the analysis simulated the field performance. The S-CLAY1S model was used in the back analyses, and half of the whole embankment cross section was simulated.

\section{Extent of Smear Zone (Ratio of $d_{s} / d_{m}$ )}

The finite-element predictions for various $d_{s} / d_{m}$ ratios are compared with the measured data in Fig. 14. The ratio of $k_{h} / k_{s}$ was kept constant as 10. As illustrated in Fig. 14, an increase in the diameter of the smear zone causes a decrease in the settlement rate of the soft subsoil. The results in Fig. 14 demonstrate that when the ratio of $d_{s} / d_{m}$ is greater than five, there is not much effect on the settlement behavior.

\section{Permeability of Smear Zone (Ratio of $\boldsymbol{k}_{\boldsymbol{h}} / \boldsymbol{k}_{\boldsymbol{s}}$ )}

In order to fit the measured data, the ratio of $k_{h} / k_{s}$ was varied from 1 to 20 in the analyses while the ratio of $d_{s} / d_{m}$ was kept constant as five. The predicted settlement-time relationship of the 


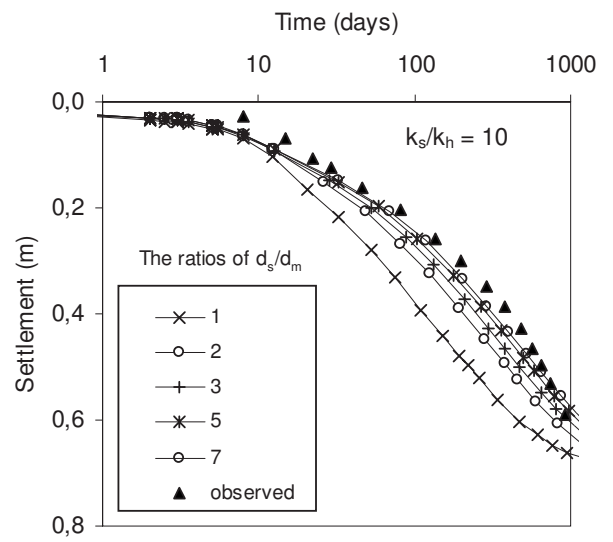

Fig. 14. Haarajoki test embankment; Cross Section 35880; effect of $d_{s} / d_{m}$ on settlement behavior (with S-CLAY1S model)

embankment on PVD-improved subsoil for various $k_{h} / k_{s}$ ratios is plotted in Fig. 15. The effect of reduced horizontal permeability in the smear zone on settlement behavior of the embankment is clearly significant. The rate of settlement decreases with an increase in the $k_{h} / k_{s}$ ratio. As shown in Fig. 15, with $k_{h} / k_{s}=20$, the numerical results agree reasonably well with the measured values.

\section{Final Simulations}

Based on the results above, a combined mapping procedure was adopted to simulate the axisymmetric drainage condition in plane strain analyses of the whole embankment, as it is computationally most convenient. Based on the studies above, the smear effect is taken into consideration by using $k_{h} / k_{s}=20$ and $d_{s} / d_{m}=5$, which is within the ranges proposed by several investigators (Bergado et al. 1993; Indraratna and Redana 1998; Bo et al. 2000; and Xiao 2001) and is of the same order of magnitude as the sensitivity of the natural soil. The equivalent plane strain width of the drain was preselected as $1 \mathrm{~m}$ and the $k_{p l}$ was calculated as $0.103 k_{a x}$ for the full plane strain analysis of the embankment by using Eq. (9).

The observed settlements and predicted vertical displacements by the three constitutive models versus time at the ground surface underneath the centerline [Fig. 16(a)] and the crest [Fig. 16(b)] of Haarajoki test embankment on PVD-improved subsoil are compared in Fig. 16 with the field measurements. The settlements predicted by the two anisotropic models (S-CLAY1 and

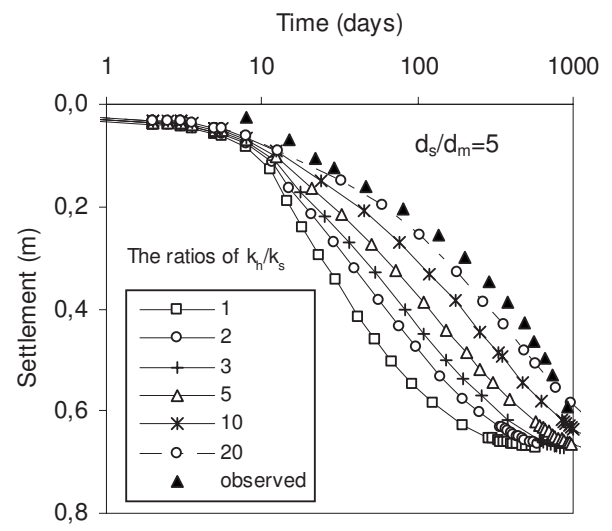

Fig. 15. Haarajoki test embankment; Cross Section 35880; effect of $k_{h} / k_{s}$ on settlement behavior (with S-CLAY1S model)

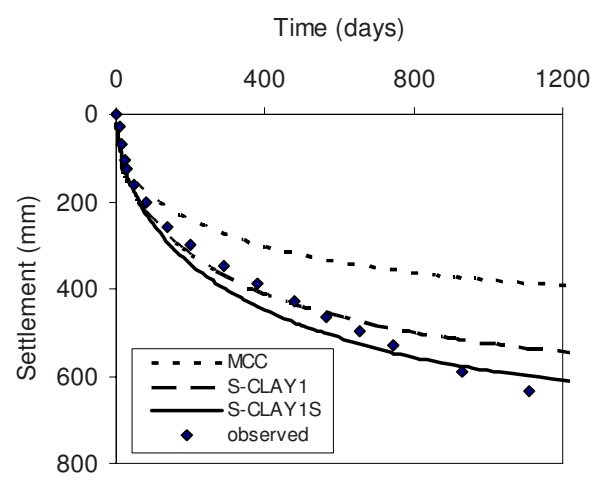

(a)

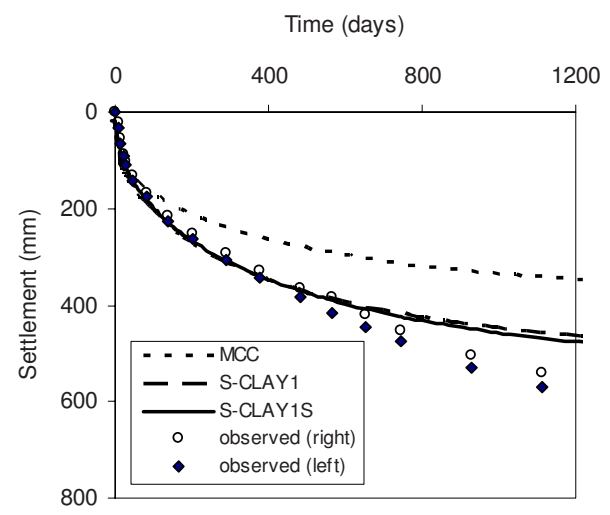

(b)

Fig. 16. Haarajoki test embankment; Cross Section 35880; timesettlement curves: (a) under centerline; (b) $4 \mathrm{~m}$ from centerline (under crest of embankment)

S-CLAY1S) after 3 years of consolidation are in good agreement with the field measurements. However, the calculated timesettlement curve predicts the settlements to slow down, whereas the observed settlements suggest that the embankment keeps on settling with a constant rate. This could be due to creep effects, which are not accounted for in the analysis. Rowe and Li (2002) pointed out that the critical period with respect to the stability of reinforced embankments on rate-sensitive soils occurs after the end of construction as a result of a buildup in excess pore-water pressure due to creep of the foundation soil. Also, Rowe and Taechakumthorn (2008) showed that the presence of PVDs not only accelerated the rate of excess pore-water dissipation but also reduced the amount of overstress in the soil, consequently the effects of viscoplastic response of the soil was minimized. They indicated that PVDs substantially reduce the effect of creepinduced excess pore pressure, and hence not only allow a faster rate of consolidation but also improve the long-term stability of the reinforced embankment. It is seen that the creep effects may be important to the behavior of embankments on PVD improved soft clays. Additionally, the rate of consolidation in the calculations is faster than measured ones. Some of this is due to the mapping effect, given the agreement between axisymmetric and equivalent plane strain analyses is not perfect. Fig. 16 again highlights the role of anisotropy in the predicted soil response.

\section{Conclusions and Future Work}

The influence of anisotropy and destructuration on the behavior of Haarajoki test embankment with sections constructed on both 
natural and PVD improved soft clay deposit has been studied. With the exception of a $2 \mathrm{~m}$ thick dry crust, the soft soil deposit under Haarajoki embankment is normally or lightly overconsolidated, and hence very compressible. The soft clay is modeled with three different constitutive models, the isotropic MCC model, the S-CLAY1 model, which accounts for plastic anisotropy and its extension, the S-CLAY1S model, that additionally accounts for bonding and destructuration. The results of the finiteelement simulations, performed as large strain analyses, were compared with the field monitoring results. Based on comparisons between the field observations and the finite-element results the following main conclusions can be drawn:

The numerical simulations demonstrate that the agreement between the finite-element predictions using the anisotropic constitutive models (S-CLAY1 and S-CLAY1S) and the field observations is generally very good. The models seem to be a significant improvement compared with the MCC model. For this particular boundary value problem ignoring the effect of anisotropy leads to notable underprediction of vertical displacements. The horizontal displacements were predicted reasonably well by the anisotropic models. The isotropic MCC model predicts notably smaller vertical settlements than the two anisotropic models and a bigger horizontal to vertical displacement ratio. The two anisotropic models (S-CLAY1, S-CLAY1S) gave qualitatively very similar predictions of the long-term settlement behavior. The S-CLAY1 model that accounts for anisotropy does not require any additional laboratory tests and therefore the use of the S-CLAY1 model does not significantly increase the difficulty of performing numerical analyses.

In the second part of the paper, 2D plane strain finite-element analysis of Haarajoki test embankment built on PVD-improved soft soil was carried out. The mapping procedures proposed by Hird et al. (1992) for the equivalent plane strain model were adopted in the study, based on the verification of the mapping procedures with advanced models (MCC, S-CLAY1, and S-CLAY1S) by Yildiz et al. (2006). In this paper, a multidrain analysis of the whole embankment on PVD-improved subsoil was performed using the combined mapping procedure by Hird et al. (1992). The back analyses showed that the settlements calculated with the S-CLAY models agreed with the field measurements when $d_{s} / d_{m}=5$ (radius of the smear zone over the radius of the mandrel) and $k_{h} / k_{s}=20$ (intact permeability over the permeability in the smear zone) which agree with the values proposed in the literature. Indeed, it was found that once $d_{s} / d_{m}>5$, increasing the ratio has no significant influence on the results, and therefore from practical point of view $k_{h} / k_{s}$ is the most important design parameter for vertical drains. The final value $\left(k_{h} / k_{s}=20\right)$ derived via the back analyses done for this paper is of a similar order of magnitude as the sensitivity of the natural clay.

In the analyses presented, each cross section of the embankment has been modeled independently as a plane strain problem. The field measurements shown by Lojander and Vepsäläinen (2001), however, suggest some interaction. Therefore in future analyses, it would be advisable to consider the 3D nature of the embankment. Because the vertical drains speed up the consolidation in the vertically drained area, the effects of creep become significant. Further investigations should consider the creep effect, using the time dependent extensions of the S-CLAY1 model proposed by Leoni et al. (2008) and Yin and Karstunen (2008).

\section{Acknowledgments}

The work presented was carried out as a part of a Research Training Network "Advanced Modelling of Ground Improvement on Soft Soils (AMGISS)" (Contract No. MRTN-CT-2004-512120) supported by the European Community through the programme "Human Resources and Mobility" and the Academy of Finland (Grant No. 210744). The first writer was supported by the Scientific and Technological Research Council of Turkey (TUBITAK) and the third writer was sponsored through a scholarship by the Faculty of Engineering, University of Strathclyde, U.K.

\section{References}

Aalto, A. (1998). "The calculations on Haarajoki test embankment with the finite element program Plaxis 6.1." Proc., 4th European Conf. on Numerical Methods in Geotechnical Engineering (NUMGE), Udine, Italy, Springer, Wien, 37-46.

Barron, R. A. (1948). "Consolidation of fine-grained soils by drain wells." Trans. Am. Soc. Civ. Eng., 113, 718-743.

Bergado, D. T., Balasubramaniam, A. S., Fannin, R. J., and Holtz, R. D. (2002). "Prefabricated vertical drains (PVDs) in soft Bangkok clay: A case study of the new Bangkok International Airport project." Can. Geotech. J., 39, 304-315.

Bergado, D. T., Chai, J. C., and Miura, N. (1995). "FE analysis of grid reinforced embankment system on soft Bangkok clay." Comput. Geotech., 17, 447-471.

Bergado, D. T., Mukherjee, K., Alfaro, M. C., and Balasubramaniam, A. S. (1993). "Prediction of vertical-band-drain performance by the finite-element method." Geotext. Geomembr., 12, 567-586.

Bo, M. W., Bawajee, R., Chu, J., and Choa, V. (2000). "Investigation of smear zone around vertical drain." Proc., 3rd Int. Conf. on Ground Imp. Techniques, CI-Premier Pte Ltd, Singapore, 109-114.

Borges, J. L., Cardoso, A. S., and Lopes, M. G. (2000). "Numerical simulation of a reinforced embankment on soft ground constructed up to failure." Proc., GeoEng2000_Int. Conf. on Geotech. and Geo. Eng., Melbourne, Australia, Technomic Publishing, Lancaster, Pa., 19-24.

Brinkgreve, R. B. J. (2002). PLAXIS, finite element code for soil and rock analyses, 2D-Version 8, Balkema, Rotterdam, The Netherlands.

Burland, J. B. (1990). "On the compressibility and shear strength of natural clays." Geotechnique, 40, 329-378.

Chai, J. C., and Bergado, D. T. (1993). "Some techniques for finite element analysis of embankments on soft ground." Can. Geotech. J., 30, 710-719.

Chai, J. C., and Miura, N. (1999). "Investigation of factors affecting vertical drain behaviour." J. Geotech. Geoenviron. Eng., 125(3), 216226.

Chai, J. C., Miura, N., Sakajo, S., and Bergado, D. T. (1995). "Behavior of vertical drain improved subsoil under embankment loading." Soils Found., 35(4), 49-61.

Chai, J. C., Shen, S. L., Miura, N., and Bergado, D. T. (2001). "Simple method of modeling pvd-improved subsoil." J. Geotech. Geoenviron. Eng., 127(11), 965-972.

Chen, W. F. (1982). Plasticity in reinforced concrete, McGraw-Hill, New York.

Cundy, M., and Neher, H. (2003). "Numerical analysis of a test embankment on soft ground using an anisotropic model with destructuration." Proc., Int. Workshop on Geotechnics of Soft Soils-Theory and Practice, Noordwijkerhout, The Netherlands, VGE Verlag GmbH, Essen, Germany, 265-270.

Dafalias, Y. F., Manzari, M. T., and Papadimitriou, A. G. (2006). "SANICLAY: Simple anisotropic clay plasticity model." Int. J. Numer. Analyt. Meth. Geomech., 30, 1231-1257.

Diaz-Rodriguez, J. H., Leroueil, S., and Alem'an, J. D. (1992). "Yielding 
of Mexico City clay and other natural clays." J. Geotech. Engrg., 118(7), 981-995.

Finnish National Road Administration (FinnRA). (1997). "Competition to calculate settlements at the Haarajoki test embankment." Competition programme, competition materials, FinnRA, Finland.

Gens, A., and Nova, R. (1993). "Conceptual bases for a constitutive model for bonded soils and weak rocks." Proc., Int. Symp. on Hard Soils-Soft Rocks, Athens, Greece, Balkema, Rotterdam, The Netherlands, 485-494.

Gnanendran, C. T., Manivannan, G., and Lo, S. C. R. (2006). "Influence of using a creep, rate, or an elastoplastic model for predicting the behaviour of embankments on soft soils." Can. Geotech. J., 43, 134154.

Hansbo, S. (1979). "Consolidation of clay by band-shaped vertical drains." Ground Eng., 12(5), 16-25.

Hansbo, S. (1981). "Consolidation of fine-grained soils by prefabricated drains." Proc., 10th Int. Conf. on Soil Mechanics and Foundation Engineering, Vol. 3, Stockholm, Sweden, Balkema, Rotterdam, The Netherlands, 677-682.

Hansbo, S. (1997). "Aspects of vertical drain design: Darcian or nonDarcian flow." Geotechnique, 47, 983-992.

Hawlader, B. C., Imai, G., and Muhunthan, B. (2002). "Numerical study of the factors affecting the consolidation of clay with vertical drains." Geotext. Geomembr., 20, 213-239.

Hird, C. C., and Kwok, C. M. (1989). "Finite element studies of interface behaviour in reinforced embankments on soft ground." Comput. Geotech., 8(2), 111-131.

Hird, C. C., Pyrah, I. C., and Russell, D. (1992). "Finite element modeling of vertical drains beneath embankments on soft ground." Geotechnique, 42(3), 499-511.

Hird, C. C., Pyrah, I. C., Russell, D., and Cinicioglu, F. (1995). "Modelling the effect of vertical drains in two-dimensional finite element analyses of embankments on soft ground." Can. Geotech. J., 32, 795807.

Indraratna, B., Balasubramaniam, A. S., and Ratnayake, P. (1994). "Performance of embankment stabilized with vertical drains on soft clay." J. Geotech. Engrg., 120(2), 257-273.

Indraratna, B., and Redana, I. W. (1997). "Plane strain modeling of smear effects associated with vertical drains." J. Geotech. Geoenviron. Eng., 123(5), 474-478.

Indraratna, B., and Redana, I. W. (1998). "Laboratory determination of smear zone due to vertical drain installation." J. Geotech. Geoenviron. Eng., 124(2), 180-184.

Indraratna, B., and Redana, I. W. (2000). "Numerical modelling of vertical drains with smear and well resistance installed in soft clay." Can. Geotech. J., 37, 132-145.

Jamiolkowski, M., and Lancellotta, R. (1981). "Consolidation by vertical drains: Uncertainties involved in prediction of settlement rates." Proc., 10th Int. Conf. Soil Mechanical and Foundation Engineering, Vol. 4, Balkema, Rotterdam, The Netherlands, 593-595.

Jamiolkowski, M., Lancellotta, R., and Wolski, W. (1983). "Precompression and speeding up consolidation: general report." Proc., 8th European Conf. of Soil Mechanics, Vol. 3, Helsinki, Balkema, Rotterdam, The Netherlands, 1201-1226.

Karstunen, M., and Koskinen, M. (2004). "Anisotropy and destructuration of Murro clay." Proc., Advances in Geotechn. Eng.-Skempton Conf., Vol. 1, Thomas Telford, London, 476-487.

Karstunen, M., and Koskinen, M. (2008). "Plastic anisotropy of soft reconstituted clays." Can. Geotech. J., 45(3), 314-328.

Karstunen, M., Krenn, H., Wheeler, S. J., Koskinen, M., and Zentar, R. (2005). "The effect of anisotropy and destructuration on the behaviour of Murro test embankment." Int. J. Geomech., 5(2), 87-97.

Kavvadas, M., and Amorosi, A. (2000). "A constitutive model for structured soils." Geotechnique, 50(3), 263-274.

Koskinen, M., Karstunen, M., and Wheeler, S. J. (2002a). "Modelling destructuration and anisotropy of a natural soft clay." Proc., 5th European Conf. on Numerical Methods in Geotech. Engineering (NUMGE), Paris, Presses de l'ENPC, Paris, 11-20.
Koskinen, M., Zentar, R., and Karstunen, M. (2002b). “Anisotropy of reconstituted POKO clay." Proc., 8th Int. Symp. on Numerical Models in Geomechanics, (NUMOG), Rome, Balkema, Lisse, 99-105.

Ladd, C. C., Foott, R., Ishihara, K., Scholosser, F., and Poulos, H. G. (1977). "Stress-deformation and strength characteristics." Proc., 9th Int. Conf. on Soil Mechanics and Foundation Engineering, Tokyo, Springer, New York, 421-494.

Leoni, M., Karstunen, M., and Vermeer, P. A. (2008). "Anisotropic creep model for soft soil." Geotechnique, 58(3), 215-226.

Leroueil, S., and Vaughan, P. R. (1990). "The general and congruent effects of structure in natural soils and weak rocks." Geotechnique, 40(3), 467-488.

Li, A. L., and Rowe, R. K. (2001). "Combined effects of reinforcement and prefabricated vertical drains on embankment performance." Can. Geotech. J., 38, 1266-1282.

Li, A. L., and Rowe, R. K. (2002). "Design considerations for embankments on rate sensitive soils." J. Geotech. Geoenviron. Eng., 128(11), 885-897.

Liu, M. D., and Carter, J. P. (2002). “A structured cam clay model.” Can. Geotech. J., 39, 1313-1332.

Lojander, M., and Vepsäläinen, P. (2001). "Competition to calculate settlements at Haarajoki test embankment." Final Rep. to Finnish Road Adminsitration Finnra Rep. No. 54/2001, Helsinki, Finland (in Finnish).

Madhav, R., Park, Y. M., and Miura, N. (1993). "Modelling and study of smear zones around band shaped drains." Soils Found., 33(4), 135147.

Mayne, P. W., and Kulhawy, F. H. (1982). "K $\mathrm{K}_{0}$-OCR relationship in soil." J. Geotech. Engrg. Div., 108(6), 851-872.

Näätänen, A., Vepsäläinen, P., and Lojander, M. (1998). "Finite element calculations on Haarajoki test embankment." Proc., 4th European Conf. on Numerical Methods in Geotechnial Engineering (NUMGE), Udine, Italy, Springer, New York, 151-160.

Neher, H. P., Wehnert, M., and Bonnier, P. G. (2001). "An evaluation of soft soil models based on trial embankments." Computer methods and advances in geomechanics, Balkema, Rotterdam, The Netherlands, 373-378.

Nova, R., Castellanza, R., and Tamagnini, C. (2003). "A constitutive model for bonded geomaterials subject to mechanical and/or chemical degradation." Int. J. Numer. Analyt. Meth. Geomech., 27(9), 705-732.

Onoue, A. (1988). "Consolidation by vertical drains taking well resistance and smear into consideration." Soils Found., 28(4), 165-174.

Rixner, J. J., Kramer, S. R., and Smith, A. D. (1986). "Prefabricated vertical drains, Vol. II: Summary of research effort." Research Rep. No. FHWA/RD-86/169, Federal Highway Administration, Washington, D.C.

Roscoe, K. H., and Burland, J. B. (1968). "On the generalized stressstrain behaviour of "wet' clay." Engineering plasticity, Cambridge University Press, Cambridge, U.K., 553-609.

Roscoe, K. H., and Schofield, A. N. (1963). "Mechanical behaviour of an idealised wet clay." Proc., 2nd European Conf. on Soil Mechanics, Vol. 1, Wiesbaden, Germany, Deutsche Gesellschaft für Erd- und Grundbau, Essen, 47-54.

Rouainia, M., and Muir Wood, D. (2000). "A kinematic hardening model for natural clays with loss of structure." Geotechnique, 50(2), 153164.

Rowe, R. K., Gnanendran, C. T., Landva, A. O., and Valsangkar, A. J. (1996). "Calculated and observed behaviour of a reinforced embankment over soft compressible soil." Can. Geotech. J., 33(2), 324-338.

Rowe, R. K., and Hinchberger, S. D. (1998). "The significance of rate effects in modelling the Sackville test embankment." Can. Geotech. J., 33, 500-516.

Rowe, R. K., and Li, A. L. (2002). "Behaviour of reinforced embankments on soft rate sensitive soils." Geotechnique, 52(1), 29-40.

Rowe, R. K., and Li, A. L. (2005). "Geosynthetic-reinforced embankments over soft foundations." Geosynthet. Int., 12(1), 50-85. 
Rowe, R. K., and Soderman, K. L. (1984). "Comparison of predicted and observed behaviour of two test embankments." Geotext. Geomembr., $1,143-160$.

Rowe, R. K., and Taechakumthorn, C. (2007). "Combined effect of PVDs and reinforcement on embankments over rate-sensitive soils." Geotext. Geomembr., 26, 239-249.

Rowe, R. K., and Taechakumthorn, C. (2008). "Combined effect of PVDs and reinforcement on embankments over rate-sensitive soils." Geotext. Geomembr., 26, 239-249.

Sanchez, J. M., and Sagaseta, C. (1990). "Analysis of staged construction of embankments on soft soil." Proc., 2nd European Speciality Conf. on Numerical Methods in Geotechnical Engineering, Santander, Spain, CEDEX, Madrid, 457-471.

Sarsby, R. W. (2007). "Use of 'limited life geotextiles' (LLGs) for basal reinforcement of embankments built on soft clay." Geotext. Geomembr., 25, 302-310.

Schaefer, U. R., and Duncan, J. M. (1988). "Finite element analyses of the St. Alban test embankment." Geotechnique Special Publication, Geosynthetics for Soil Improvement, 18, 158-177.

Sharma, J. S., and Bolton, M. D. (2001). "Centrifugal and numerical modelling of reinforced embankments on soft clay installed with wick drains." Geotext. Geomembr., 19, 23-44.

Shen, S. L., Chai, J. C., Hong, Z. S., and Cai, F. X. (2005). "Analysis of field performance of embankments on soft clay deposit with and without PVD-improvement." Geotext. Geomembr., 23(6), 463-485.

Tavenas, F., Jean, P., Leblond, P., and Leroueil, S. (1983). "The permeability of natural clays. Part II: permeability characteristics." Can. Geotech. J., 20(4), 645-660.

Tavenas, F., and Leroueil, S. (1977). "Effects of stresses and time on yielding of clays." Proc., 9th Int. Conf. on Soil Mechanics and Foundation Engineering, Vol. 1, Tokyo, 319-326.

Taylor, D. W. (1948). Fundamentals of soil mechanics, Wiley, New York.

Varuso, R. J., Grieshaber, J. B., and Nataraj, M. S. (2005). "Geosynthetic reinforced levee test section on soft normally consolidated clays." Geotext. Geomembr., 23(4), 362-383.
Wheeler, S. J., Näätänen, A., Karstunen, M., and Lojander, M. (2003). "An anisotropic elasto plastic model for soft clays." Can. Geotech. J., 40, 403-418.

Whittle, A. J., and Kavvadas, M. J. (1994). "Formulation of MIT-E3 constitutive model for overconsolidated clays." J. Geotech. Engrg., 120(1), 173-198.

Wiltafsky, C. (2003). S-CLAY1S: User defined soil model for plaxis documentation, University of Glasgow, Glasgow, U.K.

Xiao, D. P. (2001). "Consolidation of soft clay using vertical drains." Ph.D. thesis, Nanyang Technological Univ., Singapore.

Yildiz, A., Karstunen, M., and Krenn, H. (2006). "Numerical modelling of vertical drains with advanced constitutive models." Proc., 6th European Conf. on Numerical Methods in Geotechnical Engineering, Graz, Austria, Taylor \& Francis, London.

Yin, Z. Y., and Karstunen, M. (2008). "Influence of anisotropy, destructuration and viscosity on the behaviour of an embankment on soft clay." Proc., 12th Int. Conf. of Int. Association for Computer Methods and Advances in Geomechanics (IACMAG), Goa, India, 4728-4735.

Zeng, G. X., and Xie, K. H. (1989). "New development of vertical drain theories." Proc., 12th ICSMFE, Vol. 2, Rio de Janeiro, Brazil, Taylor \& Francis, London, 1435-1438.

Zentar, R., Karstunen, M., and Wheeler, S. J. (2002). "Influence of anisotropy and destructuration on undrained shearing of natural clays." Proc., 5th European Conf. on Numerical Methods in Geotechnical Engineering (NUMGE), Paris, Presses de 1'ENPC, Paris, 21-26.

Zhou, W., Hong, H. P., and Shang, J. Q. (1999). "Probabilistic design method of prefabricated vertical drains for soil improvement." J. Geotech. Geoenviron. Eng., 125(8), 659-664.

Zhou, C., and Yin, J. H. (2004). "Consolidation analyses of soils underneath Haarajoki test embankment using elastic-plastic and elastic visco-plastic models." J. of the Southeast Asian Geotech. Society, 35(1), 29-38. 